\title{
Study of Working Memory Intervention in Children with Delay in Vocabulary Development: Effects on Working Memory and Language Ability
}

\author{
Shinyoung Kim, Dongsun Yim \\ Department of Communication Disorders, Ewha Womans University, Seoul, Korea
}

Correspondence: Dongsun Yim, PhD Department of Communication Disorders, Ewha Womans University, 52 Ewhayeodae-gil, Seodamun-gu, Seoul 03760, Korea

Tel: $+82-2-3277-6720$

Fax: $+82-2-3277-2122$

E-mail: sunyim@ewha.ac.kr

Received: October 4, 2015

Revised: November 10, 2015

Accepted: November 21, 2015

This work was supported by the National Research Foundation of Korea Grant funded by the Korean government (NRF-2014S1A5A8017863)

\begin{abstract}
Objectives: Studies have carried out the base of the processing mechanism regarding language problems of children with language impairments, focusing on working memory. The purpose of this study was to examine the effects of intervention aimed at activating working memory in children with delay in vocabulary development (VD) and the subsequent effect on working memory and language ability. Methods: A total of 12 children (6 children with VD and 6 typically developing children [TD] matched by chronological age) age 5-7 were assessed through working memory tasks. Pre-post design was used to compare differences among working memory tasks (nonword repetition, Competing Language Processing Task [CLPT], and matrix) and language tasks (Receptive \& Expressive Vocabulary Test [REVT], Korean-Token Test for Children [K-TTFC], sentence repetition, and grammaticality judgment) in the VD group. Children with VD were provided with intensive intervention sessions 3 times a week for 5 weeks. Results: The research found that the VD group showed lower performance than the TD group in working memory tasks. After intervention for activating working memory, the children with VD showed improvement in one of the working memory tasks (CLPT-word recall) and several language tasks (REVT, K-TTFC, sentence repetition, reaction time for grammaticality judgment). Conclusion: Working memory intervention resulted in increased working memory capacity, improved vocabulary (REVT), auditory comprehension of language and attention (K-TTFC), and syntactic ability (sentence repetition, and grammaticality judgment). Therefore, intervention for working memory has a positive effect on not only working memory capacity but language ability as well.
\end{abstract}

Keywords: Working memory, Working memory intervention, Delay in vocabulary development, Language impairment, Language ability
언어는 의사소통의 수단이 되는 사회적 도구로써, 정상적인 언어 발달은 학업적 성취와 사회적 성공에 있어서도 중요한 요소이다. 단순언어장애(specific language impairment)는 일반적으로 인지, 청력, 기타 신경학적 결함 없이 발현되는 발달적 언어장애를 말하 는데(Stark \& Tallal, 1981), 선행연구들에 따르면 단순언어장애 아 동은 어휘발달이 또래에 비해 늦으며(Kail, Hale, Leonard, \& Nippold, 1984; Lahey \& Edwards, 1999; Leonard, Nippold, Kail, \& Hale, 1983; McGregor \& Windsor, 1996), 문법형태소 사용에 제한 을 보이고(Bortolini, Caselli, \& Leonard, 1997; Leonard, 1989; Rice
\& Oetting, 1993), 구문 영역에 있어서도 평균발화길이가 짧고 다양 한 구문구조의 사용에 어려움을 보이는 등 또래에 비해 발달이 느 린 특징을 보인다(Kim \& Pae, 2002; Lee, Kim, \& Yun, 2008; Leonard, McGregor, \& Allen, 1992; Morehead \& Ingram, 1973). 단순언 어장애 아동들은 언어발달 초기부터 이러한 특징들을 보이곤 하 며, 학령기에 접어들면서 언어를 기반으로 하는 학습 전반에 결함 을 가져옴에 따라 읽기장애와 학습장애로까지 연결(Bishop \& Adams, 1990; Rescorla, 2002)되기도 한다는 점에서 정확한 평가와 조 기 중재가 중요하다. 
단순언어장애 아동의 언어문제는 의미, 구문 및 형태, 화용론 등 언어영역 전반에 다양하게 나타나지만, 특히 제한된 어휘 발달은 단 순언어장애 아동에게서 나타나는 대표적인 지표인 것으로 많은 선 행연구들이 지목하였다(Adams \& Gathercole, 1995; Leonard, 1998; Leonard, Camarata, Rowan, \& Chapman, 1982; Montgomery, 1995; Oetting, Rice, \& Swank, 1995; Rice, Cleave, \& Oetting, 2000). 특히 낱말찾기 장애(word-finding deficit)는 단순언어장애 아동의 어휘 적 특성과 관련하여 가장 많이 보고되고 있는 것 중의 하나로서, 어 떤 상황이나 자극에 대해 특정 낱말을 산출하는 데 어려움을 갖는 것을 말한다. 낱말찾기는 이름대기(naming) 과제를 통하여 평가할 수 있는데, 단순언어장애 아동은 일반아동에 비해 이름대기 과제의 수행력이 유의하게 낮았음을 보고한 선행연구들이 있다(FriedOken, 1987; Kail et al., 1984; Leonard et al., 1983; Lee \& Kim, 2002, 2003; McGregor \& Windsor, 1996; McGregor, 1997; McGregor \& Appel, 2002).

단순언어장애 아동들은 제한된 어휘를 사용하고 짧고 단순한 구문을 산출하며 문법형태소를 적절히 사용하지 못하는 구문오류 를 보이는 등, 언어의 다른 영역보다 특히 구문 및 형태론 영역의 발 달이 느린 것으로 알려져 있다(Paul, 1993; Rescorla, Roberts, \& Dahlsgaard, 1997; Steckol \& Leonard, 1979). 문장따라말하기는 구문능 력과 높은 상관관계가 있으며(Hale-Haniff \& Siegel, 1981; Schwartz \& Daly, 1976), 아동의 문법 지식을 반영하는 과제이다. 선행연구에 의하면 구문발달이 늦거나 구문 결함을 보이는 아동들은 문장따 라말하기 과제를 수행할 때 자신의 문법 지식에 있지 않은 구문의 경우에는 어순을 바꾸어 문장을 산출하거나 문법형태소를 표현하 는 데 어려움을 보이는 경우가 많다(Kim \& Chung, 2011). 또한 단 순언어장애 아동의 문장따라말하기 수행력이 일반아동에 비해 유 의하게 낮으며(An \& Kim, 2000; Menyuk \& Looney, 1972), 문장따 라말하기 과제를 수행할 때 중요한 문법표지나 음운규칙을 처리하 고 어휘를 음운규칙에 맞추어 정확하게 회상 산출하는 데 있어서 어려움을 보임을 밝힌 선행연구 결과들이 있다(Briscoe, Bishop, \& Norbury, 2001; Eadie, Fey, Douglas, \& Parsons, 2002).

단순언어장애 아동은 일반아동에 비해 언어의 전반적인 영역에 서 지체를 보이나, 특히 문법적인 측면의 제한이 두드러진다는 것이 많은 연구들에서 보고되었다(Bishop, 1994; Cleave \& Rice, 1997; Leonard, 1998; Rice \& Oetting, 1993). 단순언어장애 아동들은 생 활연령이 비슷한 일반아동뿐만 아니라 언어연령이 비슷한 나이가 더 어린 아동에 비하여서도 미숙한 모습을 보인다고 보고되었으며 (Rice, Wexler, \& Hershberger, 1998; Rice, Wexler, \& Redmond, 1999), 국내의 선행연구에서도 단순언어장애 아동의 문법형태소
산출이 생활연령을 일치시킨 일반아동과 비교하여 지체되었음을 보인 바 있다(Jeong \& Hwang, 2007; Jung \& Pae, 2010). 선행연구에 서 문법적으로 오류가 있는 문장을 판별하게 하는 문법성판단(grammaticality judgment) 과제로 문법능력을 평가한 결과, 단순언어장 애 아동은 또래 일반아동에 비하여 정확도와 반응시간에서 모두 낮은 수행력을 보였으며(Edwards \& Kirkpatrick, 1999; Wulfeck, 1993), 국내 연구에서도 단순언어장애 아동이 또래 일반아동에 비 하여 조사오류에 대한 판단의 정확도가 낮은 것으로 나타났다(Jeong \& Hwang, 2007; Jung \& Pae, 2010).

이와 같이 단순언어장애 아동에 대한 연구는 초기에는 주로 어 휘, 구문, 형태론적 측면 등 언어의 각 영역에서의 결함에 관심을 갖 고 이를 규명하고자 하였다(Leonard, 1998). 즉, 단순언어장애 아동 이 주로 구문과 형태론적 측면에서 어려움을 보이는 것에 주목하여 단순언어장애 아동의 문법체계 및 문법형태소의 이해 및 산출에서 의 결함을 규명하려 하는(Ingram \& Morehead, 2002; Leonard, 1989; Rice \& Oetting, 1993) 접근이 주를 이루었다. 그러나 의미, 음 운, 구문, 형태, 화용 등 다양한 언어 영역에서 나타나는 단순언어 장애 아동의 언어적 결함은 광범위한 개인차를 보이며(Kim, 2004; Stark \& Tallal, 1981), 또한 단순언어장애 아동이 언어적 과제뿐만 아니라 다양한 언어적, 인지적 처리과제에서 저조한 수행력을 보임 에 따라(Bishop, 1992; Weismer, 1996), 단순언어장애 아동들에게 서 다양하게 표출되는 언어적 결함을 야기하는 기저의 문제에 대 한 관심으로 연구의 영역이 확장되었다.

최근에는 언어발달의 기저로서 작업기억에 주목하는 연구들이 많아지고 있으며(Gathercole, 1994; Just \& Carpenter, 1992; Leonard et al., 2007; Weismer, 1996), 언어장애 아동의 언어능력의 결함 을 작업기억으로 설명하는 연구가 꾸준히 있어왔다(Bishop, 1992; Gathercole \& Baddeley, 1990a; Just \& Carpenter, 1992; Kail, 1994; Leonard, 1998; Montgomery, 1995; Swanson, \& Sachse-Lee, 2001; Weismer, 1996). 선행연구에 의하면 작업기억은 어휘 습득(Gathercole, Willis, Emslie, \& Baddeley, 1992), 문법 형태소 습득(Weismer, 1996), 그리고 문장 이해(Montgomery, 2000) 등과 유의한 정 적 상관관계가 있는 것으로 나타났다. 또한 단순언어장애 아동(Montgomery, 1995; Weismer, Evans, \& Hesketh, 1999), 자폐아동(Gathercole, Alloway, Willis, \& Adams, 2006; Williams, Goldstein, \& Minshew, 2006) 등 언어발달장애 아동들이 일반적으로 일반아동 에 비해 작업기억 수행력이 낮게 나타나며, 많은 선행연구들에서 이러한 낮은 작업기억 수행력과 단순언어장애 아동의 언어결함과 의 관련성을 찾고자 하였다(Gathercole \& Baddeley, 1990a; Montgomery, 1995; Swanson \& Sachse-Lee, 2001; Waters \& Caplan, 1996). 
일반적으로 작업기억(working memory)은 제한된 양의 정보를 일시적으로 저장하고 유지하며 조작하는 인지처리과정으로 정의 할 수 있으며(Baddeley, 1986), 이러한 작업기억은 추론, 문제해결, 언어이해와 같은 복잡한 기능을 수행할 때 중심적인 역할을 한다 (Just \& Carpenter, 1992). Baddeley (1986, 2000)는 작업기억을 음운 루프(phonological loop), 시공간 스케치패드(visuospatial sketch$\mathrm{pad})$, 일화적 완충기(episodic buffer), 그리고 중앙 집행기(central executive)의 네 가지 요소로 구분하였다. 음운루프는 음운적 작업 기억과, 시공간 스케치패드는 시공간적 작업기억과 관련이 있으며, 일화적 완충기는 장기기억의 정보와 지금 기억하고자 하는 정보를 연결하고, 중앙집행기는 다른 세 가지 하위체계로부터 정보를 통합 하고 관리한다. 한편 Just와 Carpenter (1992)는 작업기억을 저장 (storage)과 처리(process)가 동시에 일어나는 작업공간으로 정의한 바 있으며, 이 모형에서는 작업기억 용량을 이러한 이원적 기능을 동시에 수행하기 위한 가용자원의 총량으로 정의한다.

언어와 작업기억, 그리고 단순언어장애 아동의 언어문제와 작업 기억 간의 상관관계가 여러 선행연구들에서 보고되면서, 아동의 언 어발달을 평가하고 언어장애를 선별하기 위한 도구로써 다양한 작 업기억 과제들이 개발되어 왔다. 음운적 작업기억은 새로운 어휘를 배우는 데에 중요한 역할을 하는데(Gathercole \& Baddeley, 1990b; Hoff, Core, \& Bridges, 2008), 아동이 새로운 어휘를 학습할 때에는 어휘집에 없는 생소한 음운 목록 조합을 일시적으로 저장하는 과 정이 필요하기 때문이다. 이러한 음운적 작업기억을 평가하기 위한 대표적인 도구로는 비단어따라말하기를 들 수 있다(Archibald \& Joanisse, 2009; Dollaghan \& Campbell, 1998; Gathercole, 2006). 많은 선행연구에서 단순언어장애 아동의 비단어따라말하기 수행 력이 일반아동에 비해 유의하게 낮음을 밝혔으며(Gathercole \& Baddeley, 1990a; Swanson \& Sachse-Lee, 2001), 낮은 음운적 작업 기억 수행력은 어휘발달(Gathercole \& Baddeley, 1990b) 및 문장 이 해(Montgomery, 1995)등에 영향을 미친다고 보고하였다. 한편 시 공간적 작업기억을 측정하는 과제로는 매트릭스(matrix) 과제가 있으며(Cowan et al., 2003; Logie, Zucco, \& Baddeley, 1990; Shah \& Miyake, 1996; Swanson, 2003), 단순언어장애 아동의 시공간적 작 업기억 수행력이 일반아동에 비해 유의하게 낮음을 밝힌 선행연구 결과들이 있다(Doehring, 1960; Montgomery, 1993; Poppen, Stark, Eisenson, Forrest, \& Wertheim, 1969). 텍스트 유형에 따른 글 이해 능력에 대한 국내의 선행연구에 의하면, 읽기에 어려움이 있는 아 동은 '묘사글'을 읽을 때 시공간 작업기억이 글 이해에 미치는 간섭 효과를 보였음을 밝히면서(Do \& Lee, 2006), 시공간 작업기억이 아 동의 글 이해에 미치는 영향을 설명하였다.
앞서 기술한 바대로 Just와 Carpenter (1992)는 작업기억 용량을 저장(storage)과 처리(process)의 기능을 동시에 수행하기 위한 가 용자원의 총량으로 정의한 바 있는데, 저장과 처리의 상호작용에 관심을 두는 대표적인 과제로 Gaunling과 Campbell이 1994년에 제작한 Competing Language Processing Task (CLPT)를 들 수 있 다. 이러한 이중처리 과제를 사용한 다수의 선행연구들(Daneman \& Carpenter, 1980; Gaulin \& Campbell, 1994; Montgomery, 1995, 2000)에서 단순언어장애 아동 집단은 일반아동 집단에 비해 저조 한 수행력을 보였다. 특히 Weismer 등(1999)은 단순언어장애 아동 을 대상으로 한 연구에서 처리 능력과 관계된 정오판단 수행력은 또래 아동과 유사하였으나, 저장 능력과 관계된 단어의 회상능력은 저조한 것으로 나타난 연구결과를 근거로 단순언어장애 아동의 기 능적 작업기억 용량이 일반아동에 비해 제한적임을 주장했다.

이렇듯 언어능력의 주요한 기저 메커니즘으로 주목받고 있는 작 업기억을 평가하고 단순언어장애를 비롯한 청각장애, 자폐범주성 장애 등 다양한 장애군의 작업기억과 언어와의 상관관계를 밝힌 선행연구들은 꾸준히 있어왔으나, 그에 비해작업기억 용량을 확대 시키거나 작업기억을 활성화시키는 치료법에 대한 연구는 미비한 실정이다. 작업기억 용량은 개인차가 있고 일반적으로 고정되어 있 다고 알려져 왔으나, 뇌의 가소성에 근거하여 작업기억 용량을 확대 시키는 중재 효과 연구가 최근 대두되고 있다. 노년층(Richmond, Morrison, Chein, \& Olson, 2011), 성인층(Kundu, Sutterer, Emrich, \& Postle, 2013), 청소년(Gibson et al., 2011), 일반아동(Loosli, Buschkuehl, Perrig, \& Jaeggi, 2012) 등 다양한 세대를 대상으로 작업기억 훈련의 효과를 입증한 연구들이 있으며, 국내에서도 $\mathrm{ADHD}$ (Kwon, 2013; Park, Park, Cho, \& Shin, 2010; Song, Kwon, \& Lee, 2013), 학 습장애(Choi, 2011; Kang \& Song, 2011), 지적장애(Ham, 2009; Kim, 2013) 아동을 대상으로 작업기억 훈련이 아동의 작업기억 용량 확 대에 유의한 효과를 가져왔음을 밝혔다. 그러나 단순언어장애 아 동의 전형적인 지표로 알려져 있는 어휘발달이 지체된 아동을 대 상으로 한 작업기억 중재 연구는 찾아보기 힘들고, 작업기억 훈련 이 중재 대상자의 작업기억 용량뿐만 아니라 언어의 다양한 영역에 미치는 영향에 대한 연구도 미비하다.

여러 선행연구들에서 지적한 바대로 언어장애 아동의 낮은 언어 능력의 기저에 작업기억이라는 근본적 처리기제의 결함이 있다면, 지능이나 신체적, 신경적 손상 없이 또래에 비해 낮은 어휘수준을 보이는 어휘발달지체 아동의 작업기억을 증진시키는 중재 프로그 램을 실시한 후 어휘발달지체 아동의 작업기억 및 언어능력이 유의 하게 향상되었는지 검토하는 연구가 필요한 때이다. 따라서 본 연구 에서는 어휘발달지체 아동을 대상으로 작업기억 중재를 실시한 후 
어휘발달지체 아동에게 표면적으로 나타난 언어문제를 비롯하여 기저의 처리 기제의 결함으로 인한 과제의 저조한 수행력이 향상될 것인가를 검토해보고자 하였다. 이를 위한 구체적인 연구문제는 다음과같다.

첫째, 어휘발달지체 아동과 일반아동의 작업기억 과제 수행력 차이가 유의한가?

둘째, 작업기억 중재에 따른 어휘발달지체 아동의 중재 전후 작 업기억 과제 수행력 차이가 유의한가?

셋째, 작업기억 중재에 따른 어휘발달지체 아동의 중재 전후 언 어능력의 차이가 유의한가?

\section{연구 방법}

\section{연구대상}

본 연구는 서울에 거주하는 생활연령 5-7세의 어휘발달지체 아 동 6 명 $(5 ; 7-7 ; 4$, 여 3 , 남 3), 그리고 이들과 생활연령을 일치시킨 일반 아동 6명(5;7-7;1, 여 3, 남 3)을 대상으로 하였다.

연구대상의 선정 기준은 다음과 같다. 어휘발달지체 아동은 (1) 수용·표현 어휘력 검사(Receptive \& Expressive Vocabulary Test, REVT; Kim, Hong, Kim, Jang, \& Lee, 2009) 결과 표현어휘력 또는 수용어휘력이 -1.25 SD 미만인 아동으로서 (2) 카우프만 아동용 지 능검사(Korean Kaufman Assessment Battery for Children, K$\mathrm{ABC}$; Moon \& Byun, 2003)의 비언어성 지능지수가 85점(-1 SD) 이 상이며, (3) 부모 또는 교사에 의해 시각, 청각, 신체 및 기타 정서 문 제가 없다고 보고된 아동으로 선정하였다. 또한 일반아동은 (1) 수 용·표현 어휘력 검사(REVT; Kim et al., 2010) 결과 표현어휘력과 수용어휘력이 정상 범주(-1 SD 이상)인 아동으로서 (2) 카우프만 아동용 지능검사(K-ABC; Moon \& Byun, 2003)의 비언어성 지능 지수가 85점(-1 SD) 이상이며, (3) 부모 또는 교사에 의해 시각, 청각, 신체 및 기타 정서 문제가 없다고 보고된 아동으로 선정하였다.

Table 1. Participants' characteristics

\begin{tabular}{lccc}
\hline Characteristic & VD group (N=6) & TD group (N=6) & $Z$ \\
\hline Age (mo) & $76.00(6.63)$ & $76.83(7.57)$ & .320 \\
REVT-R & $52.17(8.89)$ & $84.50(12.23)$ & $2.882^{*}$ \\
REVT-E & $63.50(6.09)$ & $85.33(9.77)$ & $2.727^{*}$ \\
K-ABC & $114.83(16.62)$ & $119.33(5.35)$ & 1.774 \\
\hline
\end{tabular}

Values are presented as mean (SD).

$\mathrm{VD}=$ children with delay in vocabulary development; $\mathrm{TD}=$ typically developing children; REVT = Receptive \& Expressive Vocabulary Test (Kim, Hong, Kim, Jang, \& Lee, 2009); K-ABC=Korean-Kaufman Assessment Battery for Children (Moon \& Byun, 2003).

${ }^{*} p<.01$.
본 연구에 참여한 대상자의 생활연령과 수용 및 표현 어휘력 점 수, 비언어성 지능지수의 평균 및 표준편차를 Table 1에 제시하였 다. 집단의 통제가 잘 이루어졌는지 확인하기 위하여 만-휘트니 $U$ 검정을 실시하였으며, 그 결과 두 집단의 생활연령 $(Z=.320, p>.05)$ 과 비언어성 지능 $(Z=1.774, p>.05)$ 에 통계적으로 유의한 차이가 없었고, 수용어휘력 $(Z=2.882, p<.01)$ 과 표현어휘력 $(Z=2.727$, $p<.01)$ 에서만 유의한 차이를 보였다. 본 연구의 중재 프로그램에 참여한 아동 정보는 Table 2에 제시하였다.

\section{연구절차}

본 연구는 작업기억 중재가 어휘발달지체 아동의 작업기억 용량 및 언어능력에 미치는 영향을 알아보고자 사전-사후 검사설계를 사용하였다. 사전평가, 작업기억 중재, 사후평가로 진행되었으며, 연구의 구체적인 절차는 다음과 같다.

\section{사전평가}

사전평가는 중재가 시작되기 전 대상 아동들의 작업기억 및 언 어능력을 평가하기 위하여 실시하였다. 검사는 조용한 방에서 검사 자와 대상 아동이 책상에 나란히 앉아 개별적으로 이루어졌으며, 검사 시간은 약 90 분 소요되었다. 사전평가 과제 중 따라말하기 과 제는 스마트폰(SHV-E160K)으로 녹음되었으며, 사전평가에 사용 된 과제는 다음과 같다.

\section{작업기억 평가}

대상 아동들의 작업기억을 평가하기 위하여 비단어따라말하기 과제, 문장폭 기억 과제, 매트릭스 과제를 실시하였다.

본 연구에서 사용된 비단어따라말하기(nonword repetition) 과 제는 선행연구(Lee, Kim, \& Yim, 2013; Oh \& Yim, 2013; Yang, Yim, $\mathrm{Kim}, \& \mathrm{Han}, 2013)$ 에서 사용된 과제로서, 2-6음절의 비단어 20개 로 구성되어 있다. 사전에 녹음된 비단어들이 컴퓨터를 통하여 제

Table 2. Intervention group characteristics

\begin{tabular}{lccccc}
\hline ID (gender) & Age $(\mathrm{mo})$ & Education level & REVT-R & REVT-E & K-ABC \\
\hline A (F) & 88 & 1st grader & 66 & 61 & 112 \\
B (F) & 77 & Preschooler & 53 & 61 & 103 \\
C (F) & 76 & Preschooler & 58 & 66 & 112 \\
D (M) & 75 & Preschooler & 41 & 56 & 148 \\
E (M) & 71 & Preschooler & 48 & 74 & 108 \\
F (M) & 69 & Preschooler & 47 & 63 & 106 \\
\hline
\end{tabular}

$\mathrm{F}=$ female; $\mathrm{M}=$ male; REVT=Receptive \& Expressive Vocabulary Test (Kim, Hong, Kim, Jang, \& Lee, 2009); K-ABC= Korean-Kaufman Assessment Battery for Children (Moon \& Byun, 2003). 
시되었으며, 검사자는 아동들에게 들려주는 비단어를 앵무새처럼 똑같이 따라말하도록 지시하였다.

문장폭 기억 과제(CLPT)는 선행 연구(Gaulin \& Campbell, 1994) 를 수정, 보완하여 만든 과제로서(Kim \& Yim, 2012), 검사자는 아 동에게 녹음된 음성파일을 컴퓨터로 들려주고 아동에게 예/아니요 대답과 함께 마지막 단어를 회상 산출하게 한다. 문장을 듣고 정오 를 판단하는 문장처리와 각 문장의 마지막 단어를 기억하여 회상 하는 두 가지 과정이 동시에 진행되는 과제이며, 총 42 문항에 대해 정오판단과 단어회상의 두 가지 하위 과제 각각 점수가 산출되었다.

매트릭스(matrix) 과제는 선행연구(Gathercole, Pickering, Ambridge, \& Wearing, 2000; Kim \& Yim, 2012)에서 사용한 과제를 수정, 보완하였으며, 컴퓨터 화면에 제시된 $3 \times 3$ 매트릭스 안에서 점등하는 시각 자극을 기억하여 순서를 거꾸로 회상하는 과제이 다. 검정 바탕의 컴퓨터 화면 중앙에 $3 \times 3$ 매트릭스의 흰색 사각형 9 개가 제시되며, 0.5 초의 간격으로 매트릭스의 한 칸이 주황색으로 점등된다. 점등되는 칸의 수는 2 개(난이도 1)부터 5 개(난이도 4)로 점차 늘어나며, 아동은 각 문항에서 정지화면이 나타난 후 빈 매트 릭스가 제시되면, 점등된 매트릭스의 칸을 거꾸로 회상하여 손가 락으로 짚는다.

모든 과제는 연습문항에서 아동이 과제를 완전히 숙지했다고 판 단될 때까지 반복적으로 훈련한 후 본문항을 실시하였으며, 과제 의 정확도는 정반응률로 측정하였다. 본 연구에서 사용된 작업기 억 과제들의 타당도를 검증하기 위하여 Kendall W 검증을 실시하 였으며, 그 결과 작업기억을 측정하기 위한 과제들 간 상관관계가 유의한 것으로 나타났다(Kendall W=.710, $p<.0001)$.

\section{언어능력 평가}

대상 아동들의 언어능력을 의미론적, 형태론적, 구문론적 영역 에서 다각적으로 평가하기 위하여, 선별과제로 사용한 REVT 외에 한국아동토큰검사, 문장따라말하기 과제, 문법성판단 과제를 실시 하였다.

한국아동토큰검사(Korean-Token Test for Children-2, K-TTFC-2; Shin, Kim, Chung, \& Kim, 2011)는 3-12세 아동의 청각적 언 어이해력을 평가하는 표준화 검사로서, 아동은 검사자의 구어 지 시문을 듣고 크기, 모양, 색상의 세 가지 측면에서 서로 다른 20 개의 토큰을 조작한다. 본 검사로써 아동의 듣기이해력 및 주의산만과 충동성 등 주의집중과 관련된 기타 문제 등을 평가할 수 있다.

문장따라말하기(sentence repetition) 과제는 선행연구(An \& Kim, 2000; Park, Yoon, Han, \& Yim, 2014)에서 사용된 과제를 수 정하여 문항을 구성하였으며, 각 아동들에게 컴퓨터를 통하여 음
성파일로 제시되었다. 과제의 문항은 3 낱말 단문 9 문항, 5 낱말 단문 9 문항, 5 낱말 접속문 9 문항, 5 낱말 내포문 8 문항의 총 35 문항으로 구성되었으며, 아동에게 들려주는 문장을 정확히 따라 말하도록 지시하였다. 각 문항당 모든 어절에서 정반응하였을 때 1 점을, 하나 의 어절에서라도 오반응을 보인 경우 0 점을 부과하였으며, 과제의 정확도는 정반응률로 측정하였다.

문법성판단 과제는 선행연구(An, 2013; Lee, 1996)에서 사용된 과제를 수정하여 문항을 구성하였으며, E-Prime을 사용하여 프로 그래밍한 과제를 컴퓨터로 제시하여 반응속도를 측정하였다. 과제 의 문항은 연습문항 5 개를 제외하고 비문과 정문이 각각 15 개씩 30 문항으로 구성되었으며, 컴퓨터에 흑백의 그림이 나타나고 $500 \mathrm{~ms}$ 후 그림을 설명하는 음성이 제시되면 아동이 정오를 판단하여 키 보드의 특정 버튼을 누르도록 하였다. 연습문항에서 아동이 과제 를 완전히 숙지했다고 판단될 때까지 반복적으로 훈련한 후 본문 항을 실시하였으며, 아동에게 정오판단과 동시에 최대한 빠르게 버 튼을 누르도록 지시하였다. 과제의 정확도는 정반응률로 측정하였 으며, 반응속도는 $\mathrm{ms}$ 로 측정하였다.

작업기억 과제들과 마찬가지로 본 연구에서 사용된 언어능력 측 정 과제들의 타당도 검증을 위해 Kendall W 검증을 실시하였으며, 그 결과 과제들 간 상관관계가 유의한 것으로 나타났다(Kendall $\mathrm{W}=.860, p<.0001)$

\section{중재}

본 연구에서 참고한 구어적 작업기억 중재 프로그램을 사용한 선 행연구(Choi, 2011; Ham, 2009)에 의하면, 주 3회의 총 20-21회기의 중재가 지적장애 아동 및 학습장애 아동의 언어과제 수행력 향상 에 유의한 효과를 가져왔다. 집중적인 작업기억 중재의 효과는 많 은 선행연구들에서 보고된 바(Holmes et al., 2010; Kronenberger, Pisoni, Henning, Colson, \& Hazzard, 2011), 본 연구에서도 작업기 억 중재를 각아동별로 주 3 회씩 5 주에 걸쳐 총 15 회기 실시하였다.

\section{사후 평가}

사후평가는 최종 중재가 종료된 직후 또는 3-4일(Beck, Hanson, Puffenberger, Benninger, \& Benninger, 2010; Loosli et al., 2012) 후 실시한 선행연구들을 참고하여, 적어도 중재가 종료된 후 1 주일 내 에 사전평가와 동일한 과제로 실시하였다.

\section{작업기억 중재 프로그램}

작업기억 중재 자료의 구성

본 연구에서 사용된 작업기억 중재 프로그램은 Kwon (2003)과 
Conners (2003)의 연구를 토대로 한 선행연구(Choi, 2011; Ham, 2009)에서 지적장애 아동 및 학습장애 아동을 대상으로 언어이해 력 및 언어과제 수행력에 유의한 향상을 가져온 프로그램을 수정 보완한 것으로서, 본 연구의 대상 아동의 연령과 특징을 고려하여 재구성하였다.

중재에 사용된 어휘는 그림자료로 나타내기 위하여 명사로 한정 하였다. Chang, Jeon, Shin과 Kim $(2013,2014)$ 의 연구에서 학령전 기 및 학령기 아동의 기초어휘로 선정된 명사 중 사전-사후 평가 과 제인 수용·표현 어휘력검사(Kim et al., 2010) 문항을 제외하여 사 후평가 과제에 명시적인 학습이 되지 않도록 방지하였다. 의미범주 는 해당 연구의 분류를 참고하였으며, 중재에 사용된 어휘의 목록 은 Appendix 1에 제시하였다.

시각적 범주화에 사용된 그림자료는 Microsoft Power Point 2000 을 사용하여 제시되었으며, 각 단계별로 제시되는 모든 그림은 한 슬라이드에 배치되어 아동이 화면을 보고 손가락으로 짚으며 범주 화하도록 하였다. 그림은 컬러로 제시되었으며, 매 회기는 그림자극 3 개(1단계)에서부터 7개(5단계)까지 5개 슬라이드로 구성되었다. 그림자료의 예시는 Appendix 2에 제시하였다.

\section{작업기억 중재 프로그램의 구성}

중재는 연구자와 아동이 독립된 공간에서 책상에 나란히 또는 마주앉아 진행되었으며, 각 회기는 아동의 수행력에 따라 약 30 분 에서 40 분의 시간이 소요되었다. 중재 프로그램은 매 회기 자유회 상, 시연, 청각적 언어 기억, 범주화의 네 가지 과제로 구성되었으며, 아동의 수행력은 각 과제 최종 성공 단계(단어 개수)로 기록하였다. 회기의 구성은 Table 3 에 제시하였다. 모든 과제에서 각 단계는 두 번 연속 정반응 시 다음 단계로 이행하였고, 세 번 연속 오반응 시 활동을 마쳤다. 또한 네 번 중 두 번 정반응 시 그 단계를 성공한 것 으로 간주하였다. 아동이 오반응한 경우에는 사전에 설정된 구체
적인 중재 프로토콜을 따르도록 하였다. 구체적인 회기의 내용은 Appendix 3에 제시하였다.

\section{자유회상}

이 과제에서는 연구자가 아동에게 주제단어를 제시하면, 아동이 주제단어와 관련된 단어를 회상하여 말하도록 하였다. 예를 들어, 연구자가 “동물 이름 한번 말해보자.”라고 하면, 아동은 사자, 호랑 이, 원숭이' 등 자유롭게 동물 이름을 회상하여 산출하였다. 1 분 내 에 주제단어와 관련된 단어를 10 개 이상 산출하는 것이 목표이며, 제한시간 내에 목표단어 10 개를 달성하지 못한 경우 연구자는 아 동에게 “동물원에 가면 뭐가 있지?” 등의 의미적 단서를 제공하였 다. 제한시간이 지나기 전에 아동이 연구자에게 단서 제공을 요구 하는 경우 응하지 않고 아동에게 스스로 회상하기를 격려하였다. 아동이 회상한 단어 가운데 회기의 목표단어가 없는 경우 연구자 는 해당 목표단어를 아동이 알고 있는지 확인하여, 아동의 어휘집 에 없는 단어일 경우 그 회기의 중재에 사용되는 단어에서 제외하 였다. 이는 본 연구에 사용된 작업기억 중재 프로그램이 작업기억 만을 훈련하는 것으로 어휘 학습 부담이 더해지는 것을 막기 위함 이며, 해당 어휘는 중재기록지에 별도로 기록하여 이후의 회기에서 반복적으로 상기시켜 학습할 수 있도록 하였다.

시연

이 과제에서는 연구자가 아동에게 구어로 목표단어를 하나씩 제 시하면 아동은 이를 듣고 점증적으로 목록을 늘려 순서대로 시연 (repeat)하도록 하였다. 아동에게 "기찻길 놀이를 해보자.”라고 제 안하며, 연구자가 “사자”라고 하면 아동은 “사자”라고 시연하고, 이 어서 연구자가 “호랑이”라고 하면 아동은 앞서의 단어에 덧붙여 “사자, 호랑이”라고 시연하게 하였다. 제시되는 단어의 개수는 1개 부터 최대 7 개까지로 하였으며, 각 회기의 목표어휘들은 사전에 무

Table 3. Structure of session

\begin{tabular}{|c|c|c|}
\hline Procedure (time) & Goal & Reinforcement \\
\hline 1. Opening (5 min) & Rapport forming & \\
\hline 2. Free recall (5 min) & $\begin{array}{l}\text { Recall more than } 10 \text { target vocabulary words related } \\
\text { to the topic vocabulary word (1 min time limit) }\end{array}$ & $\begin{array}{l}\text { Color the squares of graph paper corresponding with the number of vocab- } \\
\text { ulary words recalled }\end{array}$ \\
\hline 3. Rehearsal (5 min) & Present 1-7 vocabulary words & $\begin{array}{l}\text { Stamp on graph paper corresponding with the number of vocabulary words } \\
\text { demonstrated }\end{array}$ \\
\hline $\begin{array}{l}\text { 4. Auditory language recall (10 min) } \\
\text { - Recall by sequence } \\
\text { - Recall in random order }\end{array}$ & Present 2-7 vocabulary words & $\begin{array}{l}\text { Stamp on graph paper corresponding with the number of vocabulary words } \\
\text { recalled by sequence }\end{array}$ \\
\hline $\begin{array}{l}\text { 5. Categorization (10 min) } \\
\text { - Visual organization } \\
\text { - Auditory organization }\end{array}$ & Present 3-7 vocabulary words & $\begin{array}{l}\text { Sticker on graph paper corresponding with the number of vocabulary } \\
\text { words successfully organized aurally }\end{array}$ \\
\hline 6. Closing (5 min) & Wrap up and social reinforcement & \\
\hline
\end{tabular}


작위 배정되어 52 개의 목록으로 만들어져 단계별로 연구자가 선택 하여 사용할 수 있도록 하였다.

\section{청각적 언어 기억}

이 과제에서는 연구자가 아동에게 단어의 목록을 구어로 제시하 고 아동이 이를 기억하여 말하도록 하였다. 이 과제는 연구자가 들 려주는 단어의 목록을 아동이 순서대로 기억하여 말하는 과제와 순서에 상관없이 기억하여 말하는 두 개의 하위 과제로 나뉜다. "선 생님이 말하는 단어를 모두 기억해서 순서대로 말해보자.”라고 지 시한 후, 아동이 연구자가 제시한 순서와 일치하게 답하는 경우에 만 정반응으로 간주하였다. 프로토콜에 따라 과제의 한계선(ceiling)에 이른 경우, "이번에는 순서에 상관없이 선생님이 말하는 단 어를 한꺼번에 다 말해보자.”라고 지시하고, 아동이 순서에 맞지 않 게 답하여도 단어의 목록이 일치하면 정반응으로 간주하고 다음 단계로 이행하였다. 연구자가 제시하는 단어는 2 개부터 최대 7 개까 지로 하였으며, 목표어휘 목록은 단어의 개수별로 사전에 제작되 어 52 개의 목록 중 연구자가 선택하여 사용할 수 있도록 하였다.

\section{범주화}

이 과제는 자극의 종류에 따라 두 개의 하위 과제로 나뉘며, 연구 자는 두 가지 의미 범주로 분류할 수 있는 단어의 목록을 아동에게 제시하고 아동에게 범주별로 분류하여 답하도록 하였다. 제시되는 단어는 3 개부터 최대 7 개까지로 하였으며, 시각적 자극 제시 과제를 마친 후 청각적 자극 제시 과제로 이행하였다.

시각적 자극 제시 과제는 두 가지 범주로 분류할 수 있는 그림자 료를 Microsoft Power Point 2010을 사용하여 한 슬라이드에 동시 에 보여주고, 아동이 화면을 보고 각 그림의 이름대기에 정반응한 경우 “친구끼리 묶어보자.”라고 말하며 범주화하게 하였다. 아동이 그림의 이름대기에서 오반응을 보이는 경우 그림체가 친숙하지 않 아서인지 아니면 단어를 모르는 것인지 확인 후 그림체의 오인으로 인한 것인 경우에는 정반응으로 간주하였다. 아동이 범주화에 어 려움을 보이면 “이 중에서 동물을 찾아보자.”, “나머지는 뭘까?”라 고 말하며 분류기준 단서를 제공하였다. 범주화에 정반응한 경우 아동에게 “사자와 토끼는 왜 친구야?”라고 질문하여 분류기준에 대해 답하게 하였다. 여기에 오반응 시 "사자와 토끼는 동물이어서 친구야."라고 답을 알려주었다.

청각적 자극 제시 과제는 두 가지 범주로 분류할 수 있는 단어 목 록을 연구자가 아동에게 구어로 들려주고, 아동이 회상 산출한 후 범주별로 분류하게 하였다. 첫 번째 시도는 시각적 자극 제시와 동 일한 단어 목록을 사용하였으며, 회상에 오반응 시 같은 단계의 다
른 목록을 다시 아동에게 들려주었다. 회상은 순서에 상관없이 목 표 어휘를 모두 회상하면 정반응으로 간주하였으며, 회상에 정반 응 시 범주별 분류하기와 분류기준 제시하기로 이행하였다. 아동 은 회상한 단어를 두 가지 범주로 분류하고, “사자와 토끼는 동물 이어서 친구에요." "김밥과 떡은 음식이어서 친구에요.”라고 분류 기준 제시까지 정반응했을 때 그 단계를 최종적으로 성공한 것으 로 간주하였다.

\section{자료분석 및 자료의 통계적 처리}

표준화된 검사도구인 수용·표현 어휘력검사(REVT), 카우프만 아동용 지능검사(K-ABC), 그리고 한국아동토큰검사(K-TTFC-2) 의 분석은 해당 검사도구의 지침서에 따라 실시하였다. 작업기억 과 제 및 언어능력 과제는 아동의 반응을 검사가 진행되는 동안 반응 기록지에 모두 기록하였으며, 모든 과제는 문항별로 정반응한 경우 1 점, 오반응한 경우 0 점을 부과하였다. 문법성판단 과제는 컴퓨터 프로그램(E-Prime)을 통해 반응시간을 측정하였으며, 반응이 자 동적으로 기록되게 하였다. 반응시간은 정반응 문항의 반응시간만 을 측정치로 하였으며, 각 아동 평균의 $\pm 2 \mathrm{SD}$ 이상의 측정치는 가 외치(outlier)로 간주하여 제외한 후(Kail, 1994; Spaulding, 2010) 다시 반응시간의 평균을 산출하였다. 비단어따라말하기 과제는 단 어 수준 점수산출방법을 사용하였으며(Hwang, 2014), 문장따라 말하기 과제는 문장 수준 점수산출방법을 사용하였다. CLPT는 42 개의 문항별로 정오판단과 단어회상의 두 가지 하위 과제에 대하여 각각 점수가산출되었다.

어휘발달지체 아동과 일반아동의 작업기억 수행력 차이를 살펴 보기 위해 비모수통계기법 중 만-휘트니 $U$ 검정(Mann-Whitney $U$ test)을 실시하였으며, 작업기억 중재에 따른 어휘발달지체 아동의 작업기억 및 언어능력의 차이를 검정하기 위하여 비모수통계기법 중 윌콕슨 부호-서열 검정(Wilcoxon signed-ranks test)을 실시하였 다. 본 연구의 모든 통계적 분석은 SPSS Statistics 19.0을 사용하였다.

\section{연구 결과}

\section{어휘발달지체 아동과 일반아동의 작업기억 수행력 차이}

작업기억 중재 실시 전 어휘발달지체 아동과 일반아동의 작업기 억 과제 수행력에 차이가 있는지 확인하기 위하여 만-휘트니 $U$ 검 정(Mann-Whitney U-test)을 실시하였다. 두 집단의 작업기억 과제 정반응률에 대한 기술통계와 만-휘트니 $U$ 검정 결과는 Table 4, Figure 1 과 같다.

기술통계 결과 모든 과제에서 일반아동 집단의 정반응률이 높 
Table 4. Descriptive statistics and Mann-Whitney U-test results (\%) of working memory tasks by groups

\begin{tabular}{lllc}
\hline Task & \multicolumn{1}{c}{ VD $(\mathrm{N}=6)$} & $\mathrm{TD}(\mathrm{N}=6)$ & $Z$ \\
\hline CLPT accuracy & $84.13(9.84)$ & $93.65(2.88)$ & $2.012^{*}$ \\
CLPT recall & $22.62(11.64)$ & $40.87(8.70)$ & $2.406^{*}$ \\
NWR & $63.33(8.16)$ & $81.17(13.20)$ & $2.513^{*}$ \\
Matrix & $41.67(5.83)$ & $61.11(13.61)$ & $2.115^{*}$ \\
\hline
\end{tabular}

Values are presented as mean (SD).

VD = children with delay in vocabulary development; $T D=$ typically developing children; CLPT = Competing Language Processing Task; NWR= nonword repetition. ${ }^{*} p<.05$.

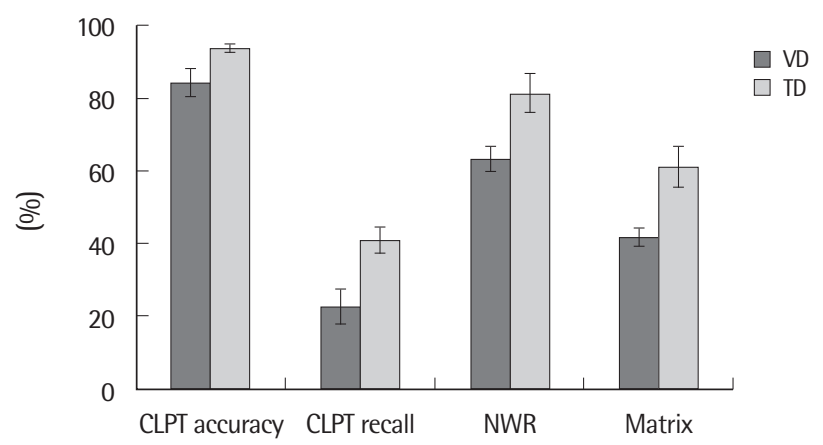

Figure 1. The performance of working memory tasks (\%) between VD and TD. $\mathrm{VD}=$ children with delay in vocabulary development; $\mathrm{TD}$ = typically developing children; CLPT = Competing Language Processing Task; NWR=nonword repetition.

은 것으로 나타났다. 통계적 유의성을 검토하기 위하여 만-휘트니 $U$ 검정(Mann-Whitney U-Test)을 실시한 결과, CLPT-정오판단 $(Z=2.012, p<.05)$, CLPT-단어회상 $(Z=2.406, p<.05)$, 비단어따 라말하기 $(Z=2.513, p<.05)$, 매트릭스 $(Z=2.115, p<.05)$ 과제 모두 집단 간 수행력 차이가 통계적으로 유의한 것으로 나타났다. 즉, 어 휘발달지체 아동 집단의 작업기억 과제 수행력이 일반아동 집단에 비해 유의하게 낮았다.

\section{작업기억 중재가 작업기억 용량에 미치는 영향}

어휘발달지체 아동을 대상으로 한 작업기억 중재가 중재 대상 아동의 작업기억 용량에 미치는 영향을 알아보기 위하여 윌콕슨 부호-서열 검정(Wilcoxon signed-rank test)을 실시하였다. 사전-사 후 작업기억 과제의 정반응률 기술통계량 및 윌콕슨 부호-서열 검 정 결과는 Table 5, Figure 2와같다.

기술통계 결과 CLPT (정오판단, 단어회상)와 매트릭스 과제의 작업기억 중재 후 정반응률이 높아졌으나, 통계적으로 유의한차이 를 보인 것은 CLPT-단어회상 $(Z=2.207, p<.05)$ 과제인 것으로 나타 났다. 즉, 작업기억 중재에 따라 어휘발달지체 아동 집단의 CLPT단어회상 과제의 수행력이 유의하게 높아졌다.
Table 5. Descriptive statistics and Wilcoxon signed-rank test results (\%) of working memory tasks at pre/post-intervention in VD group ( $\mathrm{N}=6$ )

\begin{tabular}{lccc}
\hline & Pre-intervention & Post-intervention & $Z$ \\
\hline CLPT accuracy & $84.13(9.84)$ & $88.89(7.48)$ & .943 \\
CLPT recall & $22.62(11.64)$ & $34.13(11.13)$ & $2.207^{*}$ \\
NWR & $63.33(8.16)$ & $60.83(16.25)$ & .405 \\
Matrix & $41.67(5.83)$ & $61.11(23.57)$ & 1.472 \\
\hline
\end{tabular}

Values are presented as mean (SD).

$\mathrm{VD}=$ children with delay in vocabulary development; CLPT=Competing Language Processing Task; NWR= nonword repetition.

${ }^{*} p<.05$.

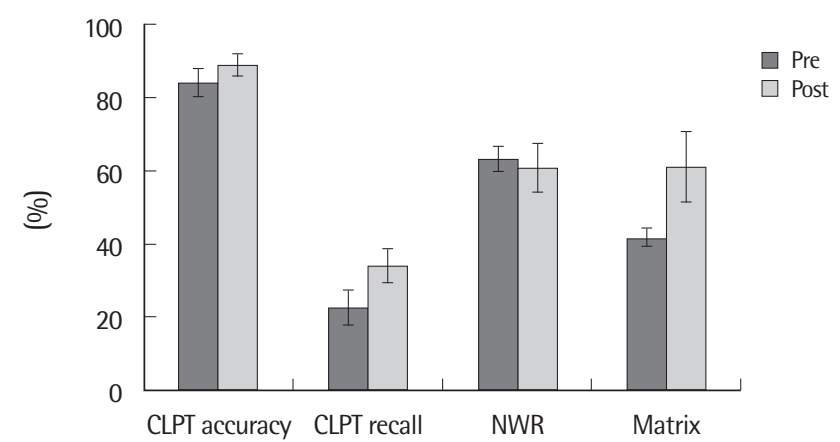

Figure 2. The performance of working memory tasks (\%) at pre/post-intervention in children with delay in vocabulary development.

\section{작업기억 중재가 언어능력에 미치는 영향}

어휘발달지체 아동을 대상으로 한 작업기억 중재가 중재 대상 아동의 언어능력에 미치는 영향을 알아보기 위하여 윌콕슨 부호서열 검정(Wilcoxon signed-rank test)을 실시하였다. 사전-사후 언 어능력 과제의 기술통계량 및 윌콕슨 부호-서열 검정 결과는 Table 6, Figures 3-5와 같다.

기술통계 결과 모든 과제의 수행력이 높아졌으며, 문법성판단정확도를 제외한 모든 과제에서 통계적으로 유의한 차이를 보였다. 즉, 작업기억 중재 후 $\operatorname{K-TTFC}(Z=2.032, p<.05), \operatorname{REVT-R}(Z=2.207$, $p<.05)$, REVT-E $(Z=1.992, p<.05)$, 문장따라말하기 $(Z=1.992$, $p<.05)$, 문법성판단-반응속도 $(Z=2.201, p<.05)$ 의 수행력이 유의 하게 향상되었다.

\section{논의 및 결론}

본 연구는 어휘발달지체 아동과 일반아동의 작업기억 용량을 CLPT, 비단어따라말하기, 매트릭스 과제 수행력으로 비교해보고, 어휘발달지체 아동 집단을 대상으로 작업기억 중재 실시 후 중재 대상 집단의 작업기억 용량 및 언어능력에 미치는 영향을 알아보 고자 하였다. 
Table 6. Descriptive statistics Wilcoxon signed-rank test results of language tasks at pre/post-intervention in VD group $(\mathrm{N}=6)$

\begin{tabular}{lccc}
\hline & Pre-intervention & Post-intervention & $Z$ \\
\hline SR (\%) & $74.76(20.64)$ & $81.90(16.92)$ & $1.992^{*}$ \\
GJT accuracy (\%) & $79.44(9.76)$ & $90.56(8.80)$ & 1.682 \\
GJT reaction time (ms) & $4,676.90(814.14)$ & $4,015.69(961.01)$ & $2.201^{*}$ \\
K-TTFC & $89.67(10.84)$ & $97.67(7.12)$ & $2.032^{*}$ \\
REVT-R & $52.17(8.89)$ & $86.17(14.32)$ & $2.207^{*}$ \\
REVT-E & $63.50(6.09)$ & $70.33(4.97)$ & $1.992^{*}$ \\
\hline
\end{tabular}

Values are presented as mean (SD).

VD=children with delay in vocabulary development; $S R=$ sentence repetition; GJT= grammaticality judgment task; K-TTFC= Korean-Token Test for Children (Shin, Kim, Chung, \& Kim, 2011); REVT=Receptive \& Expressive Vocabulary Test (Kim, Hong Kim, Jang, \& Lee, 2009).

${ }^{*} p<.05$.

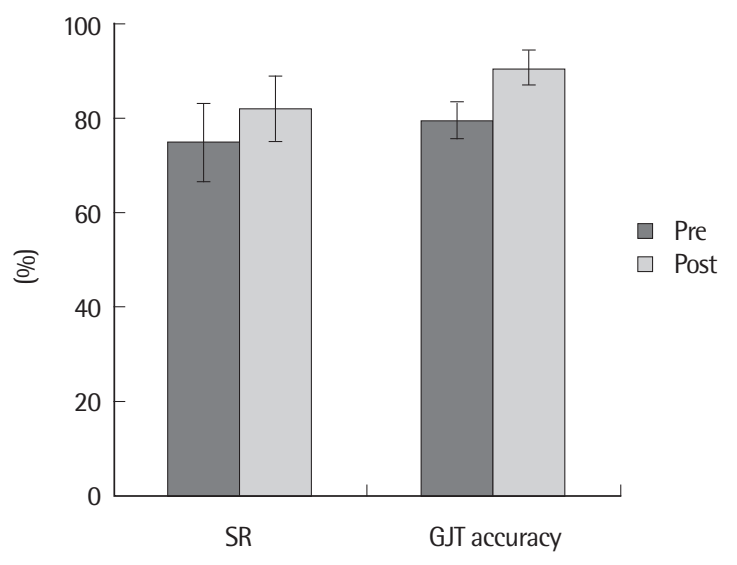

Figure 3. SR and GJT performance (\%) at pre/post-intervention in children with delay in vocabulary development. SR=sentence repetition; GJT=grammaticality judgment task.

본 연구에서 어휘발달지체 아동 집단과 일반아동 집단 간 작업 기억 용량에 차이가 있는지 알아보기 위하여 세 가지 작업기억 과 제의 집단 간 수행력 차이를 비교한 결과, CLPT와 비단어따라말하 기, 매트릭스 모두에서 집단 간 유의한 차이가 나타났다. 즉, 어휘발 달지체 아동 집단이 CLPT 정오판단 및 단어회상 모두에서 정확도 가 유의하게 낮아 어휘발달지체 아동은 정보의 저장 및 처리에 필 요한 용량이 일반아동에 비해 낮은 것으로 나타났다. 또한 음운기 억 용량을 측정하는 비단어따라말하기의 수행력도 유의하게 낮아, 음운 작업기억이 일반아동에 비해 손상되었을 뿐 아니라(Estes, Evans, \& Else-Quest, 2007; Swanson \& Sachse-Lee, 2001), 비단어 따라말하기 과제가 일반아동과 언어장애 아동을 구별할 수 있는 유용한 도구가 될 수 있다는 선행연구(Dollaghan \& Campbell, 1998 ; Weismer \& Evans, 2002) 결과를 뒷받침하였다. 또한 본 연구 결과 시공간 작업기억을 측정하기 위한 매트릭스 과제에서도 어휘

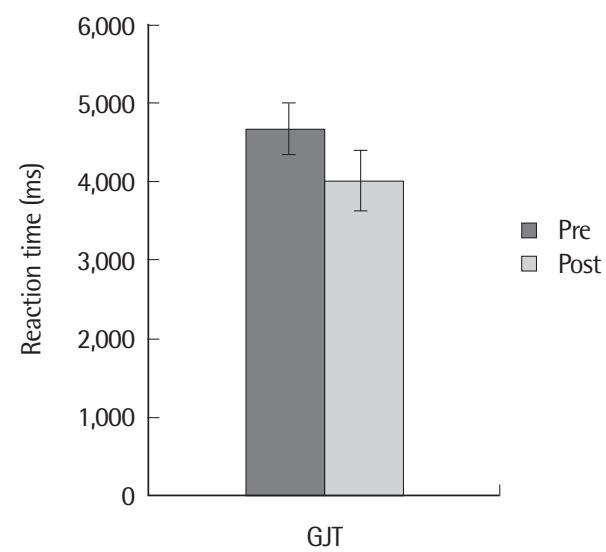

Figure 4. GJT performance at pre/post-intervention in children with delay in vocabulary development. GJT = grammaticality judgment task.

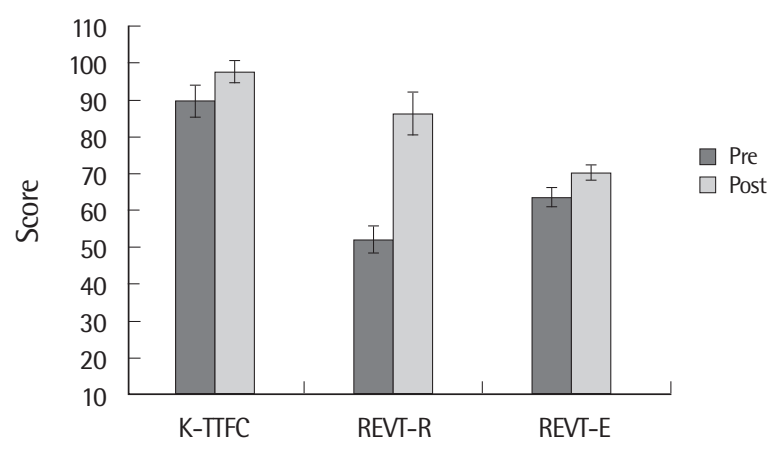

Figure 5. K-TTCF and REVT performance (\%) at pre/post-intervention in children with delay in vocabulary development. SR=sentence repetition; GJT= grammaticality judgment task; K-TTFC=Korean-Token Test for Children (Shin, Kim, Chung, \& Kim, 2011); REVT = Receptive \& Expressive Vocabulary Test (Kim, Hong, Kim, Jang, \& Lee, 2009).

발달지체 아동의 수행력이 일반아동에 비해 유의하게 낮게 나타났 다. 이는 단순언어장애 아동을 대상으로 시공간 작업기억을 평가 한 선행연구 결과(Archibald \& Gathercole, 2006; Hong \& Yim, 2014) 및 단순언어장애 아동의 시공간적 작업기억이 일반아동에 비해 한계가 있음을 밝힌 선행연구(Montgomery, 1993; Poppen et al., 1969)와 같다. 본 연구 결과 어휘발달지체 아동 집단은 일반아 동 집단에 비해 정보의 저장 및 처리의 총량으로 판단한 작업기억 용량 및 작업기억의 두 가지 하위요소인 음운기억과 시공간 작업기 억의 용량이 낮음을 확인하였다. 이에 본 연구에서는 어휘발달지 체 아동을 대상으로 구어 작업기억을 촉진하는 중재 프로그램을 적용하여 중재 전후 작업기억 용량 및 언어능력에 미치는 영향을 알아보고자 하였다.

어휘발달지체 아동을 대상으로 구어 작업기억을 촉진하는 중재 를 제공한 후 작업기억 용량에 차이가 있는지 알아보고자 중재 전 
후 세 가지 작업기억 과제의 수행력을 비교한 결과, 유의한 차이가 나타난 과제는 CLPT-단어회상인 것으로 나타났다. CLPT는 기능 적 작업기억을 측정하는 대표적인 과제로서, 정보를 저장하고 처리 하는 연합적 기능을 동시에 측정한다. 기능적 작업기억 모형에 따 르면 CLPT 과제의 정오판단과 단어회상 각각 또는 이 두 개 모두 의 수행력은 두 과제들이 이용할 수 있는 자원인 작업기억 용량을 모두 쓰면 감소하게 된다. 이 때 단어회상의 수행력은 기억 용량의 평가뿐만 아니라 처리자원이 할당되는 효율성을 나타낸다(Weismer, Evans, \& Hesketh, 1999). 본 연구 결과에 의하면 작업기억 중 재 후 어휘발달지체 아동 집단의 CLPT 과제 수행력은 기술통계 결 과 정오판단과 단어회상 모두에서 높아졌지만, 통계적으로 유의한 향상을 보인 것은 단어회상이다. CLPT의 두 개 하위과제인 저장 (단어회상)과 처리(정오판단)를 포괄한 전체 과제 수행력을 어휘발 달지체 아동의 기능적 작업기억 용량으로 본다면, 작업기억 중재를 통하여 기능적 작업기억 용량이 증가하였다고 할 수 있다. 또한 하 위과제 중 정오판단 과제가 아닌 단어회상 과제의 수행력 향상이 유의했다는 것은, Weismer 등(1999)의 설명에 따르면 중재 대상 아 동의 처리 자원이 효율적으로 할당되었다고 할 수 있다. 즉, 본 연구 를 통한 작업기억 중재로 어휘발달지체 아동의 가용할 수 있는 기 능적 작업기억 용량이 확대되었으며, 동시에 제한된 작업기억 공간 에서 자원을 공유하는 저장과 처리의 양 기능 간 효율적인 자원배 분이 일어나게 되었음을 의미한다.

한편 Baddeley (1986)의 음운작업기억 모형의 대표적인 두 가지 하위체계인 음운루프와 시공간 스케치패드의 수행력을 측정하는 비단어따라말하기와 매트릭스 과제에서는 작업기억 중재 전후 유 의한 차이가 나타나지 않았다. 이에 대해 본 연구에서 사용된 구어 작업기억 중재 프로그램은 비단어따라말하기 과제가 측정하는 음 운수준 작업기억과 달리, 중재에 사용된 어휘가 모두 실제단어(real word)인 것에 주목해볼 수 있다. 시연과 회상 활동으로 훈련된 작업 기억 영역이 어휘 수준에서 음운 수준으로 전이되지 못한 것으로 해석해볼 수 있으며, 이는 매트릭스 과제의 중재 전후 차이가 유의 하지 않은 점에서 구어 작업기억 중재의 효과가 시공간적 작업기억 영역에 전이되지 않은 것에서도 비슷하게 확인할 수 있다. 한편 작 업기억 모형에서 중앙 집행기는 음운루프와 시공간 스케치패드, 일 화적 완충기로부터 정보를 통합하고 총괄하는 상위 체계로 기능하 는데, 비단어따라말하기 과제와 매트릭스 과제가 측정하지 못하고 있는 상위영역인 중앙 집행기에 주목할 필요가 있을 것이다.

본 연구에서는 작업기억 중재가 어휘발달지체 아동 집단의 언어 능력에 미치는 영향을 어휘, 청각적 언어이해력, 문법 및 구문능력의 측면에서 검토해보고자 하였다. 유의한 차이가 나타난 것은 어휘
(REVT), 문장따라말하기, 문법성판단-반응속도, 청각적 언어이해 력(K-TTFC)이며, 문법성판단의 정확도에서는 중재 전후 유의한 차 이가 나타나지 않았다. 우선 어휘와 관련하여, REVT는 어휘 이해 및 표현 능력을 평가하는 과제로서, 수용어휘력 검사는 보기 그림 중 평가자가 들려주는 낱말을 아동이 고르도록 하며, 표현어휘력 검 사는 이름대기(naming)방법으로 아동의 어휘력을 평가한다. 이름 대기는 낱말찾기(word finding) 능력과 관계가 있는데(Kim et al., 2010), 본 연구 결과에 의하면 어휘발달지체 아동은 중재 전에 비해 중재 후 낱말찾기의 수행력이 더 높아졌다고 할 수 있다. 언어장애 아동들이 낱말찾기에 어려움을 보이는 것에 대하여 선행연구(Kail et al., 1984)에서는 저장가설(storage hypothesis)과 인출가설(retrieval hypothesis)로 설명을 했는데, 여기에서는 인출가설에 주목 하고자 한다. 낱말찾기 장애에 대해 저장가설은 제한된 어휘 저장능 력으로 설명하며(Leonard et al., 1983; McGregor, 1997; McGregor \& Windsor, 1996), 인출가설은 이미 기억 속에 저장되어 있는 어휘를 효율적이며 정확하게 인출하지 못했을 때 낱말찾기 장애가 나타난 다고 설명한다(Lee \& Kim, 2002; McGregor, 1994; McGregor \& Leonard, 1989). 본 연구에서 사용된 작업기억 중재는 목표낱말 선 정 시 REVT에 수록된 낱말을 제외하였으며, 중재 기간도 5주로서 아동의 어휘집 확장에 큰 영향을 미치지 않았을 것으로 판단된다. 그럼에도 불구하고 REVT로 평가한 어휘력이 유의하게 향상된 것 은, 작업기억 중재를 통해 대상 아동들이 이미 아동의 어휘집에 저 장되어 있었던 어휘들을 효율적이며 정확하게 인출할 수 있었음을 의미한다고볼수 있다.

문장따라말하기와 문법성판단은 아동의 구문적 능력을 평가할 수 있는 과제로서, 문법성판단의 정확도는 기술통계 결과 높아진 것으로 나타났지만 통계적으로 유의하지 않았고, 문장따라말하기 의 정반응률과 문법성판단의 반응속도는 유의하게 향상하였다. 문 장따라말하기는 제시되는 문장을 그대로 회상하기 위해 청각적으 로 입력되는 정보를 통합하고, 그 문장을 의미론 및 구문론적으로 분석하며, 산출을 계획하여 실행하는 서로 다른 인지처리 과정이 동시에 필요(Alloway, Gathercole, Willis, \& Adams, 2004)한 과제 이며, 문법성판단은 형태론적 능력만을 평가하는 것으로서, 문장 따라말하기 과제는 아동의 형태론, 구문론적 능력을 보다 다각적 으로 평가한다. 문법성판단 과제의 정반응률은 중재 전후 유의한 차이가 나타나지 않았으나 반응속도가 유의하게 빨라진 것은, 과 제를 수행하는데 필요한 아동의 처리능력 중 속도(rate)의 향상을 의미한다. 즉, 본 연구의 결과는 작업기억 중재로 Kail과 Salthouse (1994)가 처리능력을 결정하는 요소로 제시한 공간(space), 에너지 (energy), 속도(rate) 중 시간적 측면인 속도가 향상됨을 보임으로 
써, 중재 대상 아동이 처리과정에 가용할 수 있는 에너지를 더욱 효 율적으로 쓸수 있게 되었음을 보여준다.

Ullman과 Pierpont (2005)가 제안한 Procedural Deficit Hypothesis $(\mathrm{PDH})$ 에 따르면, 장기기억은 서술기억(declarative memory)과 절차기억(procedural memory)으로 나눌 수 있는데, 언어에 있어서 어휘의 측면은 서술 기억에, 문법적 측면은 절차 기억에 관계된다. 이 입장을 견지하는 선행연구들에서는, 단순언어장애 아동이 내 용어에서는 손상을 보이지 않으나 기능어에서 또래 일반아동들에 비해 낮은 수행력을 보이는 점을 경험적 연구(Tomblin, MainelaArnold, \& Zhang, 2007)를 예로 들어 밝히며, 단순언어장애 아동 이 절차기억과 관련된 뇌의 특정 영역에 문제가 있음을 주장한다. 본 연구에서 문법적/비문법적 문장을 판단하는 속도와 다양한 구 문적 능력을 평가하는 문장따라말하기 과제의 수행력에 유의한 향상을 보인 것은, 작업기억 중재에 따라 어휘발달지체 아동의 절 차기억과 관련된 문법 영역이 긍정적 영향을 받았음을 의미한다. $\mathrm{PDH}$ 에 의하면 작업기억 또한 절차기억과 관계된 뇌의 영역과 밀접 하게 연관되어 있으며, 이 영역 안의 다른 기능들과도 상호 관련되 어 있다고 한다(Ullman \& Pierpont, 2005). 즉, 절차기억은 작업기 억과도 관련이 있는 바, 본 연구의 구어 작업기억 중재 프로그램이 어휘발달지체 아동의 절차기억에 직접적인 영향을 준 것으로 볼 수 있으며, 따라서 $\mathrm{PDH}$ 를 지지한다.

한편, 중재 후 어휘발달지체 아동의 K-TTFC 점수도 유의하게 높 아졌는데, 이러한 연구결과는 K-TTFC와 작업기억 검사 간 유의한 상관관계를 밝힌 선행연구다. 본 검사는 아동의 청각적 언어이해력 을 평가하고, 동시에 주의산만과 충동성 등 주의집중과 관련된 기 타 문제를 평가하며(Shin \& Lee, 2010), 청각적 작업기억을 측정하 기 위해 사용되기도 한다(Chung \& Shin, 2012). 작업기억의 하위요 소 중 중앙집행기는 나머지 세 요소인 음운루프, 시공간적 스케치 패드, 임시적 완충기로부터 보충을 받으며 정보의 처리과정 전체를 제어하고 통제 및 판단하는 핵심적인 체계로 작동한다. 주의집중 은 중앙집행기의 기능으로서, 작업기억의 중앙집행기와 관련하여 자기조절 능력과 간섭자극에 대한 억제 및 저항 간의 상관관계를 밝힌 선행연구(Swanson \& Howell, 2001)가 있다. K-TTFC 과제는 아동의 주의집중과도 관련이 있는 과제이므로(Chung \& Shin, 2012; Shin \& Lee, 2010), K-TTFC의 수행력 향상은 작업기억 중재에 따 른 중앙집행기 기능의 활성화로 설명할 수 있다. 본 연구에서 사용 된 작업기억 중재 프로그램은 정보의 회상과 저장, 처리를 훈련하 는 프로그램으로, 구어 작업기억과 함께 아동의 주의집중을 필요 로 하였다. 따라서 K-TTFC의 수행력 향상은 본 연구에서 사용된 작업기억 중재 프로그램의 직접적 효과라고 볼 수 있으며, 나아가
작업기억의 상위영역으로 알려져 있는 집행기능(executive function)의 주요 요소가 주의집중(attention)인 것을 고려해볼 때, 후속 연구로서 집행기능으로의 전이효과까지 검토해볼 만한 결과라고 하겠다.

본 연구의 대상자는 실험집단인 어휘발달지체 아동 6 명, 통제집 단인 일반아동 6 명으로, 중재 대상자가 된 실험집단의 크기가 작아 본 연구의 결과인 작업기억 중재의 효과를 일반화시키는 것에 제한 점이 있다. 후속 연구에서는 대상자 수의 확대와, 작업기억 용량이 4 세부터 14세까지 꾸준히 발달함을 밝힌 선행연구(Gathercole et al., 2004)를 토대로 대상자 연령 범위의 확대가 필요할 것으로 보인 다. 또한 작업기억 중재의 효과를 명확히 확인하기 위해서는 실험 집단을 두 개로 나누어 한 집단에만 작업기억 중재를 실시하고 다 른 집단에는 작업기억 중재를 적용하지 않는 플라시보 통제집단 설 계가 필요하다. 그러나 본 연구에서는 플라시보 통제집단 없이 하 나의 실험집단에 대해서 작업기억 중재 전후 사전-사후 평가를 실 시하여 그 차이를 비교한 것에 제한점이 있다. 후속 연구에서는 플 라시보 통제집단을 설정하여 연구를 진행하여 연구의 내적 타당도 를 높이되, 연구종료 후 동일한 중재를 제공하는 등의 윤리적인 측 면을 고려하여야 할 것이다. 또한 본 연구에서는 연구 대상 아동에 게 시각, 청각, 기타 감각적 문제 및 정서 문제가 없음을 부모 또는 교사 보고에 의해서만 확인하였는데, 이에 대한 보다 엄밀한 검증 과정이 없었다는 것을 한계점으로 지적할 수 있을 것이다. 그리고 본 연구의 구어 작업기억 중재 프로그램의 구성 요소가 의미 단위 의 '낱말'이어서, 중재 프로그램을 수행할 때 대상 아동의 언어적 능력이 영향을 미쳤을 수 있다는 점 또한 한계점으로 생각할 수 있 다. 동일한 프로토콜을 사용하되 의미적 지식의 영향을 배제한 목 록으로 중재 프로그램을 구성하여 그 효과를 살펴보는 후속 연구 가 필요할 것으로 보인다. 한편 본 연구는 중재 연구의 특성상 사전사후 평가 시점 간 중재 대상자와 연구자 간 라포 형성에 따른 과제 수행력 차이를 간과할 수 없다. 후속연구에서는 이를 통제한 연구 설계에 대하여 고민해보아야 할 것이다. 본 연구의 결과와 관련하 여, 작업기억의 두 가지 하위영역인 음운루프와 시공간 스케치패드 를 평가하는 과제의 중재 전후 차이가 유의하지 않았으나, 중앙집 행기 기능과 관련 있는 K-TTFC에 유의한 향상을 보인 결과에 주 목하고자 한다. 집행기능(executive function)은 작업기억과 주의집 중(attention), 억제조절(inhibition), 인지적 유연성(cognitive flexibility) 등을 포괄하는 상위의 인지영역(Dawson \& Guare, 2010)으 로 알려져 있는 바, 집행기능과의 관련성을 후속연구를 통해 검토 해볼수 있을 것이다. 


\section{REFERENCES}

Adams, A. M., \& Gathercole, S. E. (1995). Phonological working memory and speech production in preschool children. Journal of Speech, Language, and Hearing Research, 38, 403-414.

Alloway, T. P., Gathercole, S. E., Willis, C., \& Adams, A. M. (2004). A structural analysis of working memory and related cognitive skills in young children. Journal of Experimental Child Psychology, 87, 85-106.

An, H. (2013). Correlation between serial reaction time task and grammaticality judgement task in multi-culture children with SLI (Master's thesis). Ewha Womans University, Seoul, Korea.

An, J., \& Kim, Y. T. (2000). The effect of syntactic complexity on sentence repetition performance and intelligibility between specific language impairment and normal children. Speech Science, 7, 249-262.

Archibald, L. M., \& Gathercole, S. E. (2006). Short-term and working memory in specific language impairment. International Journal of Language \& Communication Disorders, 41, 675-693.

Archibald, L. M., \& Joanisse, M. F. (2009). On the sensitivity and specificity of nonword repetition and sentence recall to language and memory impairments in children. Journal of Speech, Language, and Hearing Research, $52,899-914$.

Baddeley, A. D. (1986). Working memory. Oxford: Oxford University Press.

Baddeley, A. D. (2000). The episodic buffer: a new component of working memory? Trends in Cognitive Sciences, 4, 417-423.

Beck, S. J., Hanson, C. A., Puffenberger, S. S., Benninger, K. L., \& Benninger, W. B. (2010). A controlled trial of working memory training for children and adolescents with ADHD. Journal of Clinical Child \& Adolescent Psychology, 39, 825-836.

Bishop, D. V. (1992). The underlying nature of specific language impairment. Journal of Child Psychology and Psychiatry, 33, 3-66.

Bishop, D. V. (1994). Grammatical errors in specific language impairment: competence or performance limitations? Applied Psycholinguistics, 15, 507550 .

Bishop, D. V., \& Adams, C. (1990). A prospective study of the relationship between specific language impairment, phonological disorders and reading retardation. Journal of Child Psychology and Psychiatry, 31, 1027-1050.

Bortolini, U., Caselli, M. C., \& Leonard, L. B. (1997). Grammatical deficits in Italian-speaking children with specific language impairment. Journal of Speech, Language, and Hearing Research, 40, 809-820.

Briscoe, J., Bishop, D. V., \& Norbury, C. F. (2001). Phonological processing, language, and literacy: a comparison of children with mild-to-moderate sensorineural hearing loss and those with specific language impairment. Journal of Child Psychology and Psychiatry, 42, 329-340.

Chang, H. J., Jeon, H. S., Shin, M. S., \& Kim, H. J. (2013). A study on selection of basic vocabulary for infants and toddlers. Journal of Speech-Language \& Hearing Disorders, 22, 169-187.

Chang, H. J., Jeon, H. S., Shin, M. S., \& Kim, H. J. (2014). Study on selection of basic vocabulary for elementary school students: focused on basic vocabulary in the lower grades. Journal of Speech-Language \& Hearing Disorders, 23, 157-170.

Choi, S. (2011). The effects of vocabulary acquisition, reading task and selfefficacy of children with learning disabilities by working memory promotion training. Korean Journal of Learning Disabilities, 8, 31-46.

Chung, B. J., \& Shin, M. J. (2012). Does the Korean-Token Test for Children-2 (K-TTFC-2) reflect performance on memory tasks in children aged 3 to 10 years? Korean Journal of Communication Disorders, 17, 15-23.

Cleave, P. L., \& Rice, M. L. (1997). An examination of the morpheme be in children with specific language impairment: the role of contractibility and grammatical form class. Journal of Speech, Language, and Hearing Research, 40, 480-492.

Conners, F. A. (2003). Phonological working memory difficulty and related interventions. In J. A. Rondal \& S. Buckley (Eds.), Speech and language intervention in Down syndrome (pp. 31-48). London: Whurr.

Cowan, N., Towse, J. N., Hamilton, Z., Saults, J. S., Elliott, E. M., Lacey, J. F., ... \& Hitch, G. J. (2003). Children's working-memory processes: a responsetiming analysis. Journal of Experimental Psychology: General, 132, 113-132.

Daneman, M., \& Carpenter, P. A. (1980). Individual differences in working memory and reading. Journal of Verbal Learning and Verbal Behavior, 19, 450-466.

Dawson, P., \& Guare, R. (2010). Executive skills in children and adolescents: a practical guide to assessment and intervention (2nd ed.). New York: Guilford Press.

Do, K. S., \& Lee, E. (2006). Effects of text types and working memory on text comprehension in reading normal and reading deficient children. Korean Journal of Cognitive Science, 17, 191-206.

Doehring, D. G. (1960). Visual spatial memory in aphasic children. Journal of Speech \& Hearing Research, 3, 138-149.

Dollaghan, C., \& Campbell, T. F. (1998). Nonword repetition and child language impairment. Journal of Speech, Language, and Hearing Research, 41, 1136-1146. 
Eadie, P. A., Fey, M. E., Douglas, J. M., \& Parsons, C. L. (2002). Profiles of grammatical morphology and sentence imitation in children with specific language impairment and Down syndrome. Journal of Speech, Language, and Hearing Research, 45, 720-732.

Edwards, H. T., \& Kirkpatrick, A. G. (1999). Metalinguistic awareness in children: a developmental progression. Journal of Psycholinguistic Research, 28, 313-329.

Estes, K. G., Evans, J. L., \& Else-Quest, N. M. (2007). Differences in the nonword repetition performance of children with and without specific language impairment: a meta-analysis. Journal of Speech, Language, and Hearing Research, 50, 177-195.

Fried-Oken, M. (1987). Qualitative examination of children's naming skills through test adaptations. Language, Speech, and Hearing Services in Schools, 18, 206-216.

Gathercole, S. E. (1994). Neuropsychology and working memory: a review. Neuropsychology, 8, 494-505.

Gathercole, S. E. (2006). Nonword repetition and word learning: the nature of the relationship. Applied Psycholinguistics, 27, 513-543.

Gathercole, S. E., Alloway, T. P., Willis, C., \& Adams, A. M. (2006). Working memory in children with reading disabilities. Journal of Experimental Child Psychology, 93, 265-281.

Gathercole, S. E., \& Baddeley, A. D. (1990a). Phonological memory deficits in language disordered children: Is there a causal connection? Journal of Memory and Language, 29, 336-360.

Gathercole, S. E., \& Baddeley, A. D. (1990b). The role of phonological memory in vocabulary acquisition: a study of young children learning new names. British Journal of Psychology, 81, 439-454.

Gathercole, S. E., Pickering, S. J., Ambridge, B., \& Wearing, H. (2004). The structure of working memory from 4 to 15 years of age. Developmental Psychology, 40, 177-190.

Gathercole, S. E., Willis, C. S., Emslie, H., \& Baddeley, A. D. (1992). Phonological memory and vocabulary development during the early school years: a longitudinal study. Developmental Psychology, 28, 887-898.

Gaulin, C. A., \& Campbell, T. F. (1994). Procedure for assessing verbal working memory in normal school-age children: some preliminary data. Perceptual and Motor Skills, 79, 55-64.

Gibson, B. S., Gondoli, D. M., Johnson, A. C., Steeger, C. M., Dobrzenski, B. A., \& Morrissey, R. A. (2011). Component analysis of verbal versus spatial working memory training in adolescents with ADHD: a randomized, controlled trial. Child Neuropsychology, 17, 546-563.
Hale-Haniff, M., \& Siegel, G. M. (1981). The effect of context on verbal elicited imitation. Journal of Speech and Hearing Disorders, 46, 27-30.

Ham, E. (2009). The effect of working memory training program on the verbal working memory achievement and language comprehension in children with intellectual disabilities (Master's thesis). Daegu University, Gyeongsan, Korea

Hoff, E., Core, C., \& Bridges, K. (2008). Non-word repetition assesses phonological memory and is related to vocabulary development in 20- to 24-montholds. Journal of Child Language, 35, 903-916.

Holmes, J., Gathercole, S. E., Place, M., Dunning, D. L., Hilton, K. A., \& Elliott, J. G. (2010). Working memory deficits can be overcome: impacts of training and medication on working memory in children with ADHD. Applied Cognitive Psychology, 24, 827-836.

Hong, H., \& Yim, D. (2014). Working memory subsytems and receptive vocabulary in children with specific language impairment. Journal of SpeechLanguage \& Hearing Disorders, 23, 35-44.

Hwang, M. (2014). Working memory of children with reading comprehension difficulty: sentence repetition and nonword repetition. Korea Journal of Learning Disabilities, 11, 53-72.

Ingram, D., \& Morehead, D. (2002). Morehead \& Ingram (1973) revisited. Journal of Speech, Language, and Hearing Research, 45, 559-563.

Jeong, M., \& Hwang, M. (2007). Grammaticality judgments in children with specific language impairment: detection of erroneous case-markers. Korean Journal of Communication Disorders, 12, 587-606.

Jung, K., \& Pae, S. (2010). The grammaticality judgment in school-aged children with specific language impairment. Korean Journal of Communication Disorders, 15, 619-631.

Just, M. A., \& Carpenter, P. A. (1992). A capacity theory of comprehension: individual differences in working memory. Psychological Review, 99, 122149.

Kail, R. (1994). A method for studying the generalized slowing hypothesis in children with specific language impairment. Journal of Speech, Language, and Hearing Research, 37, 418-421.

Kail, R., Hale, C. A., Leonard, L. B., \& Nippold, M. A. (1984). Lexical storage and retrieval in language-impaired children. Applied Psycholinguistics, 5, 37-49.

Kail, R., \& Salthouse, T. A. (1994). Processing speed as a mental capacity. Acta Psychologica, 86, 199-225.

Kang, J., \& Song, H. (2011). Effects of cognitive enhancement program through computer on improving learning ability: focused on children of commu- 
nity social youth centers. Journal of Rehabilitation Psychology, 18, 393-407.

Kim, H., \& Yim, D. (2012). The performance on working memory span task in children with high-function autism. Korean Journal of Communication Disorders, 17, 451-465.

Kim, J. S., \& Chung, S. M. (2011). Sentence repetition performance according to length and structure of sentences in 3 to 5 year-old children. Journal of Speech-Language \& Hearing Disorders, 20, 19-36.

Kim, S. (2004). Functional working memory and word learning of Korean children with specific language impairment. Korean Journal of Communication Disorders, 9, 78-99.

Kim, S. Y., \& Pae, S. (2002). The use of grammatical morphemes of Korean children with language impairment. Speech Science, 9, 77-91.

Kim, Y. S. (2013). The effects of working memory training in utilization of audio-visual communication on word retrieval of children with intellectual disability (Master's thesis). Daegu University, Gyeongsan, Korea.

Kim, Y. T., Hong, G. H., Kim, K. H., Jang, H. S., \& Lee, J. Y. (2010). Receptive \& expressive vocabulary test (REVT). Seoul: Seoul Community Rehabilitation Center.

Kronenberger, W. G., Pisoni, D. B., Henning, S. C., Colson, B. G., \& Hazzard, L. M. (2011). Working memory training for children with cochlear implants: a pilot study. Journal of Speech, Language, and Hearing Research, 54, 1182-1196.

Kundu, B., Sutterer, D. W., Emrich, S. M., \& Postle, B. R. (2013). Strengthened effective connectivity underlies transfer of working memory training to tests of short-term memory and attention. Journal of Neuroscience, 33, 8705-8715.

Kweon, Y. H. (2003). Relation of verbal working memory to sentence comprehension in children with specific language impairment (Master's thesis). Dankook University, Seoul, Korea.

Kwon, S. (2013). Evaluation of development and effectiveness of Kwon's software for improvement of working memory and activation of the frontal lobes of attention deficit and hyperactivity disorder children (Doctoral dissertation). Daegu University, Gyeongsan, Korea.

Lahey, M., \& Edwards, J. (1999). Naming errors of children with specific language impairment. Journal of Speech, Language, and Hearing Research, 42, 195-205.

Lee, H. J., Kim, Y. T., \& Yim, D. (2013). Non-word repetition performance in Korean-English bilingual children. International Journal of Speech-Language Pathology, 15, 375-382.

Lee, H. J., Kim, Y. T., \& Yun, H. R. (2008). Characteristics of syntactic com- plexity in school-aged children with specific language impairment: a comparison of conversation and expository discourses. Korean Journal of Communication Disorders, 13, 103-121.

Lee, Y. (1996). Comparison study on the meta-linguistic awareness between normal and language-disordered children (Master's thesis). Ewha Womans University, Seoul, Korea.

Lee, Y. \& Kim, Y. T. (2002). Word-finding abilities in children with specific language impairment. Korean Journal of Communication Disorders, 7, 6580.

Lee, Y. \& Kim, Y. T. (2003). Effects of semantic priming on word-finding ability of children with specific language impairment. Korean Journal of Communication Disorders, 8, 22-39.

Leonard, L. B. (1989). Language learnability and specific language impairment in children. Applied Psycholinguistics, 10, 179-202.

Leonard, L. B. (1998). Children with specific language impairment. Cambridge, MA: MIT Press.

Leonard, L. B., Camarata, S., Rowan, L. E., \& Chapman, K. (1982). The communicative functions of lexical usage by language impaired children. Applied Psycholinguistics, 3, 109-125.

Leonard, L. B., McGregor, K. K., \& Allen, G D. (1992). Grammatical morphology and speech perception in children with specific language impairment. Journal of Speech, Language, and Hearing Research, 35, 1076-1085.

Leonard, L. B., Nippold, M. A., Kail, R., \& Hale, C. A. (1983). Picture naming in language-impaired children. Journal of Speech, Language, and Hearing Research, 26, 609-615.

Leonard, L. B., Weismer, S. E., Miller, C. A., Francis, D. J., Tomblin, J. B., \& Kail, R. V. (2007). Speed of processing, working memory, and language impairment in children. Journal of Speech, Language, and Hearing Research, 50, 408-428.

Logie, R. H., Zucco, G. M., \& Baddeley, A. D. (1990). Interference with visual short-term memory. Acta Psychologica, 75, 55-74.

Loosli, S. V., Buschkuehl, M., Perrig, W. J., \& Jaeggi, S. M. (2012). Working memory training improves reading processes in typically developing children. Child Neuropsychology, 18, 62-78.

McGregor, K. K. (1994). Use of phonological information in a word-finding treatment for children. Journal of Speech, Language, and Hearing Research, 37, 1381-1393.

McGregor, K. K. (1997). The nature of word-finding errors of preschoolers with and without word-finding deficits. Journal of Speech, Language, and Hearing Research, 40, 1232-1244. 
McGregor, K. K., \& Appel, A. (2002). On the relation between mental representation and naming in a child with specific language impairment. Clinical Linguistics \& Phonetics, 16, 1-20.

McGregor, K. K., \& Leonard, L. B. (1989). Facilitating word-finding skills of language-impaired children. Journal of Speech and Hearing Disorders, 54, 141-147.

McGregor, K. K., \& Windsor, J. (1996). Effects of priming on the naming accuracy of preschoolers with word-finding deficits. Journal of Speech, Language, and Hearing Research, 39, 1048-1058.

Menyuk, P., \& Looney, P. L. (1972). Relationships among components of the grammar in language disorder. Journal of Speech, Language, and Hearing Research, 15, 395-406.

Montgomery, J. W. (1993). Haptic recognition of children with specific language impairment: effects of response modality. Journal of Speech, Language, and Hearing Research, 36, 98-104.

Montgomery, J. W. (1995). Sentence comprehension in children with specific language impairment: the role of phonological working memory. Journal of Speech, Language, and Hearing Research, 38, 187-199.

Montgomery, J. W. (2000). Verbal working memory and sentence comprehension in children with specific language impairment. Journal of Speech, Language, and Hearing Research, 43, 293-308.

Moon, S., \& Byeon, C. (2003). Korean-Kaufman Assessment Battery for Children $(K-A B C)$. Seoul: Hakjisa.

Morehead, D. M., \& Ingram, D. (1973). The development of base syntax in normal and linguistically deviant children. Journal of Speech, Language, and Hearing Research, 16, 330-352.

Oetting, J. B., Rice, M. L., \& Swank, L. K. (1995). Quick incidental learning (QUIL) of words by school-age children with and without SLI. Journal of Speech, Language, and Hearing Research, 38, 434-445.

Oh, D. Y., \& Yim, D. (2013). Non-word repetition and sentence repetition performance in 2-3 years old late talkers and normal children. Communication Sciences \& Disorders, 18, 277-287.

Park, M. Y., Park, S. M., Cho, S. Z., \& Shin, M. S. (2010). The effect of CBTbased training using computer games for ADHD children. Korean Journal of Clinical Psychology, 29, 639-657.

Park, W. J., Yoon, S. R., Han, B. Y., \& Yim, D. (2014). A comparison of scoring methods on the sentence repetition test in Korean children with delayed language development. Journal of Speech-Language \& Hearing Disorders, 23, 17-29.

Paul, R. (1993). Outcomes of early expressive language delay. Journal of Child- hood Communication Disorders, 15, 7-14.

Poppen, R., Stark, J., Eisenson, J., Forrest, T., \& Wertheim, G. (1969). Visual sequencing performance of aphasic children. Journal of Speech, Language, and Hearing Research, 12, 288-300.

Rescorla, L. (2002). Language and reading outcomes to age 9 in late-talking toddlers. Journal of Speech, Language, and Hearing Research, 45, 360-371.

Rescorla, L., Roberts, J., \& Dahlsgaard, K. (1997). Late talkers at 2: outcome at age 3. Journal of Speech, Language, and Hearing Research, 40, 556-566.

Rice, M. L., Cleave, P. L., \& Oetting, J. B. (2000). The use of syntactic cues in lexical acquisition by children with SLI. Journal of Speech, Language, and Hearing Research, 43, 582-594.

Rice, M. L., \& Oetting, J. B. (1993). Morphological deficits of children with sli: evaluation of number marking and agreement. Journal of Speech, Language, and Hearing Research, 36, 1249-1257.

Rice, M. L., Wexler, K., \& Hershberger, S. (1998). Tense over time: the longitudinal course of tense acquisition in children with specific language impairment. Journal of Speech, Language, and Hearing Research, 41, 1412-1431.

Rice, M. L., Wexler, K., \& Redmond, S. M. (1999). Grammaticality judgments of an extended optional infinitive grammar: evidence from English-speaking children with specific language impairment. Journal of Speech, Language, and Hearing Research, 42, 943-961.

Richmond, L. L., Morrison, A. B., Chein, J. M., \& Olson, I. R. (2011). Working memory training and transfer in older adults. Psychology and Aging, $26,813-822$

Schwartz, A. H., \& Daly, D. A. (1976). Some explicit guidelines for constructing and scoring elicited imitation tasks. Language, Speech, and Hearing Services in Schools, 7, 33-41.

Shah, P., \& Miyake, A. (1996). The separability of working memory resources for spatial thinking and language processing: an individual differences approach. Journal of Experimental Psychology: General, 125, 4-27.

Shin, M. J., Kim, Y. T., Chung, B. J., \& Kim, J. O. (2011). Korean-Token Test for Children-2 (K-TTFC-2). Seoul: Hakjisa.

Shin, M. J., \& Lee, H. R. (2010). The validity of the TTFC-K for preschool children. Korean Journal of Communication Disorders, 15, 34-42.

Song, K., Kwon, S., \& Lee, J. (2013). The effect of working memory training using a software program for working memory and pre-frontal lobe activation in the children with ADHD. Korea Journal of Learning Disabilities, 10, 111-130.

Spaulding, T. J. (2010). Investigating mechanisms of suppression in preschool children with specific language impairment. Journal of Speech, Language, 
and Hearing Research, 53, 725-738.

Stark, R. E., \& Tallal, P. (1981). Selection of children with specific language deficits. Journal of Speech and Hearing Disorders, 46, 114-122.

Steckol, K. F., \& Leonard, L. B. (1979). The use of grammatical morphemes by normal and language-impaired children. Journal of Communication Disorders, 12, 291-301.

Swanson, H. L. (2003). Age-related differences in learning disabled and skilled readers' working memory. Journal of Experimental Child Psychology, 85, $1-31$.

Swanson, H. L., \& Howell, M. (2001). Working memory, short-term memory, and speech rate as predictors of children's reading performance at different ages. Journal of Educational Psychology, 93, 720-734.

Swanson, H. L., \& Sachse-Lee, C. (2001). A subgroup analysis of working memory in children with reading disabilities. Domain-general or domainspecific deficiency? Journal of Learning Disabilities, 34, 249-263.

Tomblin, J. B., Mainela-Arnold, E., \& Zhang, X. (2007). Procedural learning in adolescents with and without specific language impairment. Language Learning and Development, 3, 269-293.

Ullman, M. T., \& Pierpont, E. I. (2005). Specific language impairment is not specific to language: the procedural deficit hypothesis. Cortex, 41, 399-433.
Waters, G. S., \& Caplan, D. (1996). The capacity theory of sentence comprehension: critique of Just and Carpenter (1992). Psychological Review, 103, 761-772.

Weismer, S. E. (1996). Capacity limitations in working memory: the impact on lexical and morphological learning by children with language impairment. Topics in Language Disorders, 17, 33-44.

Weismer, S. E., \& Evans, J. L. (2002). The role of processing limitations in early identification of specific language impairment. Topics in Language Disorders, 22, 15-29.

Weismer, S. E., Evans, J., \& Hesketh, L. J. (1999). An examination of verbal working memory capacity in children with specific language impairment. Journal of Speech, Language, and Hearing Research, 42, 1249-1260.

Williams, D. L., Goldstein, G., \& Minshew, N. J. (2006). The profile of memory function in children with autism. Neuropsychology, 20, 21-29.

Wulfeck, B. B. (1993). A reaction time study of grammaticality judgments in children. Journal of Speech, Language, and Hearing Research, 36, 1208-1215.

Yang, Y., Yim, D., Kim, S., \& Han, J. (2013). The relationship among receptive vocabulary, non-word repetition, and quick incidental learning in preschoolers with and without delay in vocabulary development. Communication Sciences \& Disorders, 18, 379-391. 
Appendix 1. 중재 어휘 목록

\begin{tabular}{|c|c|}
\hline 동물 & $\begin{array}{l}\text { 닭, 부엉이, 비둘기, 참새, 오리, 펭귄 } \\
\text { 개, 고양이, 곰, 기린, 돼지, 말, 사슴, 사자, 호랑이 } \\
\text { 여우, 염소, 원숭이, 코끼리, 토끼, 하마, 소, 양, 쥐 } \\
\text { 거북이, 공룡, 악어, 뱀, 개구리 }\end{array}$ \\
\hline 곤충 & 개미, 나비, 벌 \\
\hline 채소, 곡물 & 감자, 고구마, 당근, 무, 배추, 호박, 콩, 밤, 쌀 \\
\hline 과일 & 감, 딸기, 메론, 바나나, 배, 복숭아, 오렌지, 토마토, 귤, 수박, 포도 \\
\hline 음식 & $\begin{array}{l}\text { 라면, 김밥, 짜장면, 햄버거, 피자, 핫도그, 스파게티, 샌드위치 } \\
\text { 국, 밥, 빵, 떡, 김치, 계란, 생선, 고기, 김, 닭고기 } \\
\text { 물, 우유, 콜라, 주스, 사이다 } \\
\text { 설탕, 소금, 치즈, 껌, 사탕, 초콜릿, 케이크, 도넛, 아이스크림 }\end{array}$ \\
\hline 사람 & $\begin{array}{l}\text { 가수, 간호사, 의사, 선생님, 학생, 군인, 요리사 } \\
\text { 고모, 엄마, 아빠, 삼촌, 누나, 동생, 언니, 오빠, 이모, 형, 할머니 } \\
\text { 아기, 아들, 딸, 여자, 남자, 아저씨, 아줌마, 어른, 어린이, 친구 }\end{array}$ \\
\hline 장소 & $\begin{array}{l}\text { 가게, 유치원, 은행, 수영장, 아파트, 약국, 시장, 서점, 슈퍼마켓 } \\
\text { 목욕탕, 동물원, 도서관, 병원, 박물관, 회사, 학교, 집, 공원 } \\
\text { 부억, 방, 화장실 }\end{array}$ \\
\hline 의류, 장신구 & $\begin{array}{l}\text { 바지, 치마, 팬티, 잠바, 잠옷, 양말, 신발, 구두, 운동화 } \\
\text { 가방, 허리띠, 장갑, 목도리, 안경, 지갑, 우산, 모자, 목걸이 }\end{array}$ \\
\hline 신체 & $\begin{array}{l}\text { 가슴, 귀, 눈, 목, 발목, 배, 배꼽, 손가락, 발 } \\
\text { 어깨, 얼굴, 엉덩이, 입, 허리, 팔, 턱, 등, 코 }\end{array}$ \\
\hline 자연 & $\begin{array}{l}\text { 강, 하늘, 해, 비, 불, 별, 달, 눈 } \\
\text { 숲, 잔디, 산, 길, 바람, 모래, 돌, 땅 } \\
\text { 꽃, 나무 }\end{array}$ \\
\hline 가구 & 식탁, 소파, 피아노, 침대, 의자, 옷장 \\
\hline 가전제품 & 세탁기, 에어컨, 전화, 청소기, 카메라, 라디오, 핸드폰, 텔레비전, 전자레인지 \\
\hline 물건 & $\begin{array}{l}\text { 숟가락, 젓가락, 수건, 휴지, 포크, 치약, 칼, 접시, 쟁반, 쓰레기통 } \\
\text { 상자, 비누, 병, 달력, 걸레, 빗자루, 옷걸이, 빗, 거울, 못, 열쇠 } \\
\text { 공책, 지우개, 편지, 가위, 종이, 블록, 비눗방울, 크레파스, 시계 }\end{array}$ \\
\hline 탈것 & 비행기, 유모차, 자전거, 트럭, 버스, 배, 기차, 헬리콥터, 오토바이 \\
\hline 운동 & 태권도, 축구, 수영, 야구 \\
\hline 기타 & 돈, 그네 \\
\hline
\end{tabular}


Appendix 2. 중재 그림 자료의 예
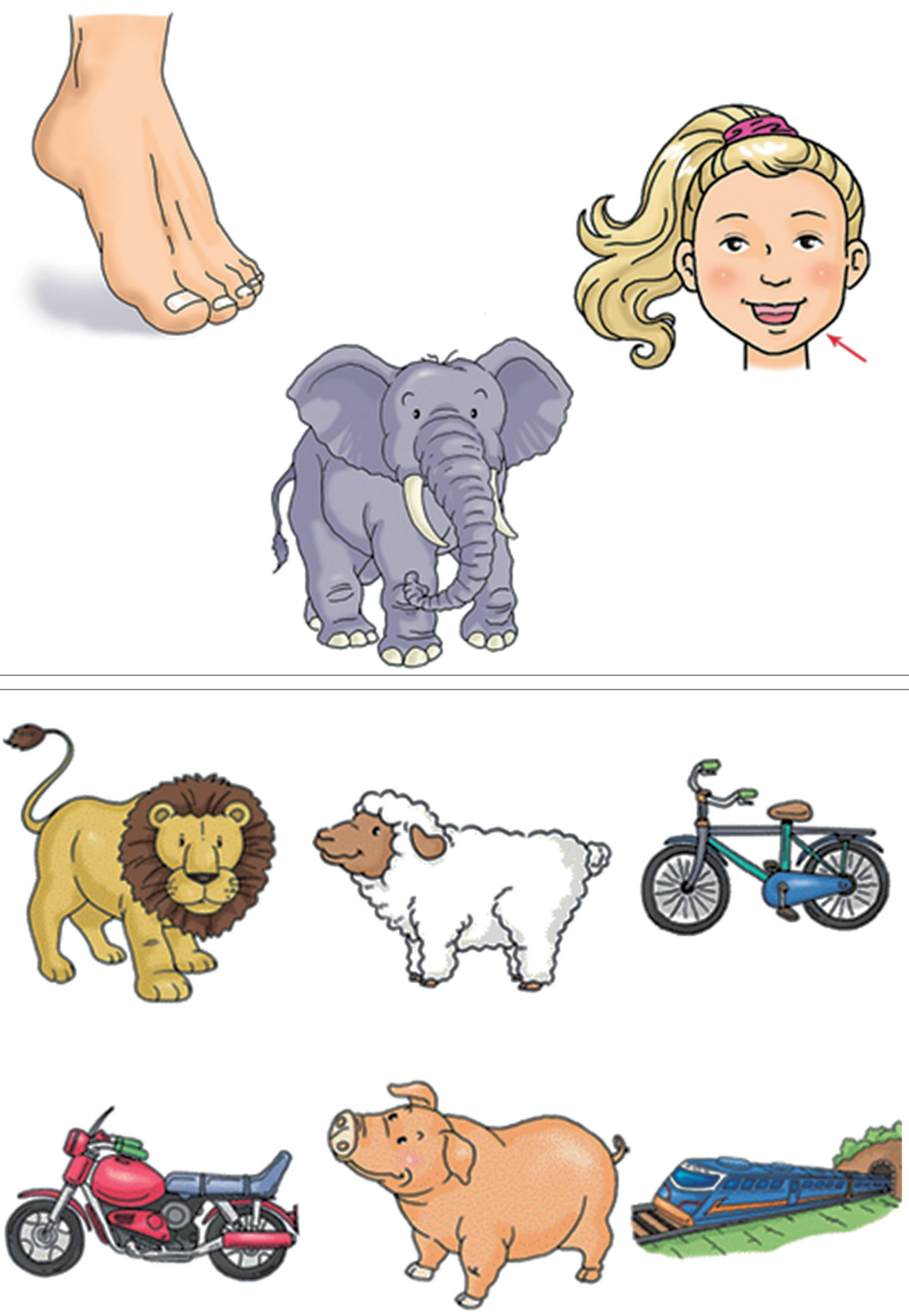
Appendix 3. 회기계획서의 예

\begin{tabular}{|c|c|c|c|}
\hline 시간 & 세부계획(활동 및 문맥) & 목표 & 강화절차/준거 \\
\hline 5분(도입) & $\begin{array}{l}\text { (1) 아동과 인사를 나눈 후, 착석한다. } \\
\text { (2) 아동과 오늘 하루 있었던 일 등에 대해 간단한 이야기를 나눈다. }\end{array}$ & & 아동별 모눈 \\
\hline 5분(자유회상) & $\begin{array}{l}\text { (1) SLP가 주제단어를 제시한다. } \\
\text { 동물 이름 한번 말해보자. } \\
\text { (2) 주제단어와 관련된 단어를 아동에게 생각하여 말하게 한다. (1분) } \\
\text { (3) } 1 \text { 분 내에 주제단어와 관련된 단어를 } 10 \text { 개 이상 회상하면 강화하고 활동을 마친다. } \\
\text { (4) 오반응 시 } \\
\text { (4)-1 (제한시간 내에 아동이) “생각이 안 나요." } \\
\text { 조금만 더 생각해보자. (단서제공X) } \\
\text { (4)-2 (1분 초과했을 때 } 10 \text { 개 미만인 경우) 의미적 단서 제공 } \\
\text { 동물원에 가면 뭐가 있지? } \\
\text { (5) 회상단어 } 10 \text { 개를 채우면 강화하고 활동을 마친다. } \\
\text { (6) 목표단어 목록의 단어들을 아동에게 이야기해주면서 아동의 어휘집에 있는지 확인한다. } \\
\text { 아동의 어휘집에 없는 경우 단어에 대해 설명해주고, 남은 활동의 어휘목록에서 제외한다. }\end{array}$ & $\begin{array}{l}\text { 주제단어와 관련된 목표 } \\
\text { 단어 } 10 \text { 개 이상 회상 } \\
\text { (제한시간 1분) }\end{array}$ & $\begin{array}{l}\text { 회상한 단어의 수만큼 모 } \\
\text { 눈종이에 색칠을 할 수 } \\
\text { 있게 한다. }\end{array}$ \\
\hline 5분(시연) & $\begin{array}{l}\text { (1) 규칙설명 } \\
\text { > 기찻길 만드는 것처럼 선생님이 말하는 것을 기억했다가 연결해서 차례로 말해보는 거예요. } \\
\text { 아동이름으로 연습 } \\
\text { (2) SLP가 아동에게 단어를 구어로 하나씩 제시한다. } \\
\text { (3) 아동은 SLP가 들려준 단어를 듣고 기억했다가 순서대로 따라말한다. } \\
\text { (4) 단어는 2개(1단계)부터 시작한다. } \\
\text { 매 trial마다 아동에게 이전의 단어목록을 머릿속에서 지우도록 주지시킨다. : } \\
\text { "머릿속에서 지우개로 지우자." } \\
\text { (5) 아동이 활동의 규칙을 충분히 이해할 수 있을 때까지 반복한다. } \\
\text { (6) 프로토콜을 따라 활동을 진행한다. }\end{array}$ & 단어 2-7개 & $\begin{array}{l}\text { 시연한 단어의 수만큼 모 } \\
\text { 눈종이에 도장을 찍을 } \\
\text { 수 있게 한다. }\end{array}$ \\
\hline
\end{tabular}




\section{국문초록}

\section{어휘발달지체 아동을 대상으로 한 작업기억 중재가 작업기억 및 언어능력에 미치는 영향 김신영 · 임동선 \\ 이화여자대학교 언어병리학과}

배경 및 목적: 언어장애 아동이 보이는 언어문제에 대해 기저의 처리 기제에 관심을 갖는 연구들이 꾸준히 있어 왔으며, 많은 연구들이 작업기억에 주목하였다. 본 연구에서는 어휘발달지체(VD) 아동의 작업기억을 활성화하는 중재가 대상 아동의 작업기억 및 언어능력 에 미치는 영향을 검토해보고자 하였다. 방법: 본 연구는 총 12 명의 아동(VD 아동 6 명, 이들과 생활연령을 일치시킨 일반아동 6 명)을 대상으로 작업기억 과제 수행력 차이를 검토하고, 사전사후 설계로 VD 집단(5;7-7;4)을 대상으로 5 주간 주 3 회의 집중적인 작업기억 중 재를 실시한 후 중재 전후의 작업기억 과제(비단어따라말하기, CLPT, matrix) 및 언어능력 과제(REVT, K-TTFC, 문장따라말하기, 문 법성판단)의 수행력을 비교하였다. 결과: 본 연구의 결과 $\mathrm{VD}$ 집단이 일반아동 집단에 비해 세 가지 작업기억 과제의 수행력이 모두 유 의하게 낮은 것으로 나타났다. 작업기억 중재 후 VD 집단의 작업기억 과제 수행력은 CLPT (단어회상)에서 유의한 향상을 보였으며, 언 어능력 과제는 REVT, K-TTFC, 문장따라말하기, 문법성판단(반응속도)의 수행력이 유의하게 향상되었다. 논의 및 결론: 본 연구에서 사용한 구어 작업기억 중재 프로그램이 VD 집단의 작업기억 용량을 확대하고, 어휘(REVT) 및 청각적 언어이해력과 주의집중력(K$\mathrm{TTFC}$, 구문능력(문장따라말하기, 문법성판단)을 향상시킨 것으로 나타났다. 즉, 작업기억에 직접적으로 개입하여 중재함으로써 작업 기억과 나아가 언어능력에까지 미치는 영향을 검토했다는 데에 의의가 있다.

핵심어: 작업기억, 작업기억 중재, 어휘발달지체, 언어장애, 언어능력

이 논문은 2014년도 정부(교육부)의 재원으로 한국연구재단의 지원을 받아 연구되었음(NRF-2014S1A5A8017863).

\section{참고문헌}

강재정, 송현주(2011). 컴퓨터를 이용한 인지증진 프로그램의 학습능력 향상효과: 지역사회 청소년센터 아동 대상. 재활심리연구, 18, 393-407.

권상남(2013). 주의력결핍 과잉행동장애 아동의 작업기억 향상과 전두엽 활성화를 위한 Kwon's 소프트웨어 개발 및 효과성 평가. 대구대학교대학원 박사학위논문.

권유현(2003). 단순언어장애 아동의 언어성 작업기억과 문장이해간의 관계. 단국대학교대학원 석사학위논문.

김성수(2004). 단순언어장애 아동의 기능적 작업기억과 낱말 습득 특성. 언어청각장애연구, 9, 78-88.

김수영, 배소영(2002). 언어발달지체 아동의 문법형태소 사용 특성. 음성과학, 9, 77-91.

김영선(2013). 청·시각적 전달을 활용한 작업기억 훈련이 지적장애 아동의 단어인출에 미치는 영향. 대구대학교 대학원 석사학위논문.

김영태, 홍경훈, 김경희, 장혜성, 이주연(2010). 수용·표현 어휘력 검사(REVT). 서울: 장애인종합복지관.

김정숙, 정승문(2011). 문장의 길이와 구조에 따른 3-5세 아동의 문장 따라말하기 수행력. 언어치료연구, 20, 19-36.

김희진, 임동선(2012). 과제 난이도에 따른 고기능 자폐아동의 작업기억 수행능력. 언어청각장애연구, 17, 451-465.

도경수, 이은주(2006). 텍스트 유형과작업기억이 읽기 정상 아동과 읽기 지진 아동의 텍스트 이해에 미치는 영향. 인지과학, 17, 191-206.

문수백, 변창진(2003). K-ABC 교육·심리측정도구(Korean-Kaufman assessment battery for children). 서울: 학지사.

박미영, 박순말, 조성준, 신민섭(2010). ADHD 아동을 위한 컴퓨터 훈련 프로그램 기반 CBT 효과 검증 한국심리학회지 임상, 29, 639-657.

박원정, 윤사라, 한보연, 임동선(2014). 한국어 문장따라말하기 검사의 점수체계 비교 연구. 언어치료연구, 23, 17-29.

송기범, 권상남, 이지윤(2013). 컴퓨터프로그램을 이용한작업기억훈련이 $\mathrm{ADHD}$ 아동의 작업기억과 전전두활성화에 미치는 효과. 학습장애연구, 10 ,

111-130.

신문자, 김영태, 정부자, 김재옥(2011). 한국 아동 토큰 검사(Korean-Token Test For Children-2: K-TTFC-2). 서울: 학지사 심리검사연구소. 
신문자, 이희란(2010). 아동용 토큰검사(TTFC-K)의 공인타당도와 내용타당도 연구: 학령전 아동을 중심으로. 언어청각장애연구, 15, 34-42. 안지숙, 김영태(2000). 단순언어장애 아동과 정상 아동의 구문적 난이도에 따른 문장따라말하기: 수행력 및 명료도 비교. 음성과학, 7,262-275. 안하영(2013). 다문화가정 아동의 연속 반응시간 과제(SRT)의 수행 능력과 문법성판단능력 간의 상관 연구. 이화여자대학교대학원 석사학위논문. 양윤희, 임동선, 김신영, 한지윤(2013). 학령 전 어휘발달지체 및 일반 아동의 비단어 따라 말하기, 빠른 우연학습과 수용어휘와의 관계. 언어청각장애 연구, 18, 379-391.

오다연, 임동선(2013). 2-3세 말 늦은 아동과 정상 아동의 비단어따라말하기와 문장 따라말하기 수행 능력. 언어청각장애연구, 18, $277-287$. 이윤경(1996). 언어장애 아동과 일반 아동의 메타언어 인식 비교 연구. 이화여자대학교대학원 석사학위논문. 이윤경, 김영태(2002). 단순언어장애아동의 낱말찾기 특성. 언어청각장애연구, 7, 65-80.

이윤경, 김영태(2003). 의미적 점화가 단순언어장애 아동의 낱말찾기에 미치는 영향. 언어청각장애연구, 8, 22-39.

이현정, 김영태, 윤혜련(2008). 담화유형에 따른 학령기 단순언어장애 아동의 구문사용 특성: 대화와 설명 담화를 중심으로. 언어청각장애연구, 13 , 103-121.

장현진, 전희숙, 신명선, 김효정(2013). 영·유아의 기초 어휘 선정 연구. 언어치료연구, 22, 169-187.

장현진, 전희숙, 신명선, 김효정 (2014). 초등학생 교육용 기초 어휘 선정 연구: 저학년 중심으로. 언어치료연구, 23, 157-170.

정경희, 배소영(2010). 초등 저학년 단순언어장애 아동의 문법형태소 판단 능력. 언어청각장애연구, 15, 619-631.

정미란, 황민아(2007). 단순언어장애 아동의 문법성 판단: 조사 오류를 중심으로. 언어청각장애연구, 12, 587-606.

정부자, 신문자(2012). 토큰검사와 단기 및 작업 기억 검사 결과 간의 관련성: 3-10세 한국 아동을 대상으로. 언어청각장애연구, 17, 15-23. 최세민(2011). 작업기억 활성화 훈련이 학습장애아동의 어휘습득과 언어과제수행 및 자기효능감에 미치는 영향. 학습장애연구, 8, 31-46.

함은선(2009). 작업기억훈련 프로그램이 지적장애아동의 언어이해 및 언어성 작업기억 수행에 미치는 효과. 대구대학교대학원 석사학위논문. 홍현주, 임동선(2014). 단순언어장애 아동의 작업기억 하위체계와수용어휘능력 간의 관계. 언어치료연구, 23, 35-44.

황민아(2014). 읽기이해부진 아동의 작업기억 특성: 문장 따라말하기 및 비단어 따라말하기 검사를 중심으로. 학습장애연구, 11, 53-72. 